\title{
Life Cycle of Oil and Gas Fields in the Mississippi River Delta: A Review
}

\author{
John W. Day ${ }^{1, *}$, H. C. Clark ${ }^{2}$, Chandong Chang ${ }^{3 \oplus}$, Rachael Hunter ${ }^{4, *}$ and Charles R. Norman ${ }^{5}$ \\ 1 Department of Oceanography and Coastal Sciences, Louisiana State University, Baton Rouge, LA 70803, USA \\ 2 Department of Earth, Environmental and Planetary Science, Rice University, Houston, TX 77005, USA; \\ hcclark@rice.edu \\ 3 Department of Geological Sciences, Chungnam National University, Daejeon 34134, Korea; cchang@cnu.ac.kr \\ 4 Comite Resources, Inc., P.O. Box 66596, Baton Rouge, LA 70896, USA \\ 5 Charles Norman \& Associates, P.O. Box 5715, Lake Charles LA 70606, USA; charles_norman@bellsouth.net \\ * Correspondence: johnday@lsu.edu (J.W.D.); rhuntercri@gmail.com (R.H.)
}

Received: 20 April 2020; Accepted: 20 May 2020; Published: 23 May 2020

\begin{abstract}
Oil and gas (O\&G) activity has been pervasive in the Mississippi River Delta (MRD). Here we review the life cycle of O\&G fields in the MRD focusing on the production history and resulting environmental impacts and show how cumulative impacts affect coastal ecosystems. Individual fields can last 40-60 years and most wells are in the final stages of production. Production increased rapidly reaching a peak around 1970 and then declined. Produced water lagged O\&G and was generally higher during declining O\&G production, making up about $70 \%$ of total liquids. Much of the wetland loss in the delta is associated with $O \& G$ activities. These have contributed in three major ways to wetland loss including alteration of surface hydrology, induced subsidence due to fluids removal and fault activation, and toxic stress due to spilled oil and produced water. Changes in surface hydrology are related to canal dredging and spoil placement. As canal density increases, the density of natural channels decreases. Interconnected canal networks often lead to saltwater intrusion. Spoil banks block natural overland flow affecting exchange of water, sediments, chemicals, and organisms. Lower wetland productivity and reduced sediment input leads to enhanced surficial subsidence. Spoil banks are not permanent but subside and compact over time and many spoil banks no longer have subaerial expression. Fluid withdrawal from $O \& G$ formations leads to induced subsidence and fault activation. Formation pore pressure decreases, which lowers the lateral confining stress acting in the formation due to poroelastic coupling between pore pressure and stress. This promotes normal faulting in an extensional geological environment like the MRD, which causes surface subsidence in the vicinity of the faults. Induced reservoir compaction results in a reduction of reservoir thickness. Induced subsidence occurs in two phases especially when production rate is high. The first phase is compaction of the reservoir itself while the second phase is caused by a slow drainage of pore pressure in bounding shales that induces time-delayed subsidence associated with shale compaction. This second phase can continue for decades, even after most O\&G has been produced, resulting in subsidence over much of an oil field that can be greater than surface subsidence due to altered hydrology. Produced water is water brought to the surface during O\&G extraction and an estimated 2 million barrels per day were discharged into Louisiana coastal wetlands and waters from nearly 700 sites. This water is a mixture of either liquid or gaseous hydrocarbons, high salinity (up to $300 \mathrm{ppt}$ ) water, dissolved and suspended solids such as sand or silt, and injected fluids and additives associated with exploration and production activities and it is toxic to many estuarine organisms including vegetation and fauna. Spilled oil has lethal and sub-lethal effects on a wide range of estuarine organisms. The cumulative effect of alterations in surface hydrology, induced subsidence, and toxins interact such that overall impacts are enhanced. Restoration of coastal wetlands degraded by $O \& G$ activities should be informed by these impacts.
\end{abstract}


Keywords: oil and gas production; produced water; oil and gas wetland impacts; induced subsidence; wetland restoration

\section{Introduction}

The first successful oil well was drilled in Louisiana in 1901 in southwestern Louisiana, in the Jennings field and marked the beginning of oil and gas (O\&G) production in Louisiana that, by the mid-20th century, was the state's primary industry [1]. Production of petroleum has been widespread in the Mississippi River Delta (MRD) and there is a dense network of pipelines both inshore and offshore (Figure 1). Hydrocarbon extraction in the MRD necessitated the dredging of canals through wetlands and waterbodies for navigation, pipelines, and O\&G extraction. As canals were dredged, spoil material from canals was placed on the side of canals partially impounding wetlands; altering natural hydrology and salinity; decreasing nutrient, organic matter, and sediment exchange; changing vegetation composition and reducing vegetation productivity (e.g., [2-5]).

To understand the impacts of O\&G activity on MRD wetlands, it is important to recognize that wetland degradation in O\&G fields occurred much more rapidly (decades) than the natural deltaic cycle, which took place over centuries to millennia [5-10]. Naturally-occurring geologic faulting, sediment compaction, the delta lobe cycle, variability in river discharge, global sea-level change, tidal exchange, wave erosion, and storms such as hurricanes and frontal passages have shaped the MRD landscape for thousands of years [5-15]. However, in less than a century, more than 30,000 km of canals were dredged in the MRD [16-18], causing dramatic wetland loss (e.g., [9]) due to cumulative effects [4,19] of altered surface hydrology, induced subsidence and fault activation [20], and toxicity of produced water and spilled oil [21-23].

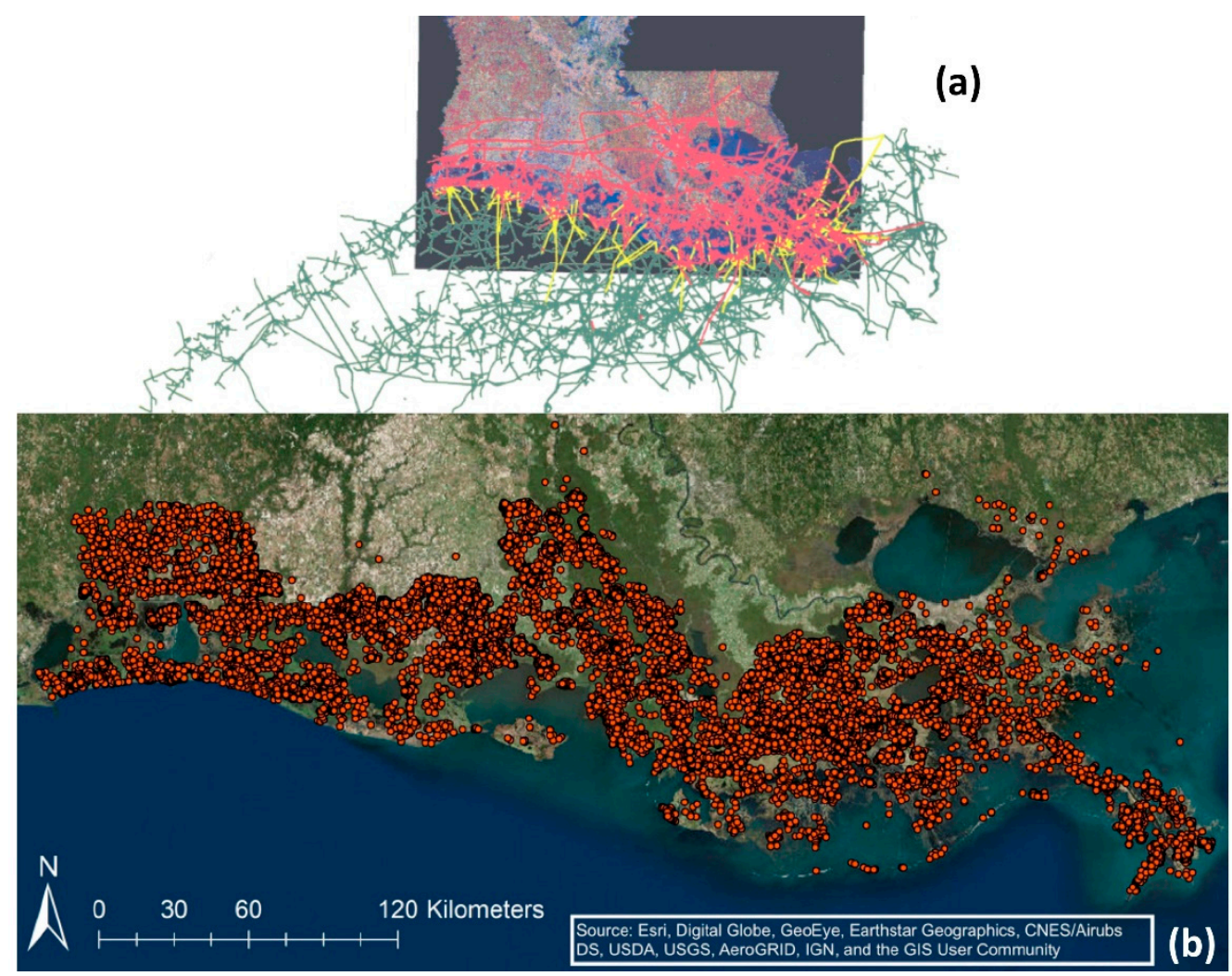

Figure 1. (a) Map of oil and gas pipelines in coastal Louisiana (http://www.dnr.louisiana.gov/assets/ docs/oilgas/data/SLA_Pipelines.pdf) and (b) the distribution of oil and gas well permits issued between 1900 and 2017 that were 'plugged' or 'abandoned' as of 2017 in the 14 coastal parishes [18]. 
Our objective in this paper is to review the literature on the life cycle of O\&G fields in the MRD by (1) describing the production history of hydrocarbons and produced water and (2) reviewing the impacts of surface alterations, induced subsidence, and toxic materials. Although, these impacts have been well documented, their interacting affects have been less well addressed. Thus, an important objective is to consider their cumulative and indirect impacts on coastal ecosystems, especially wetlands, in the MRD and to show how this information informs restoration.

\section{Production History of Oil and Gas Fields}

Hydrocarbon extraction has occurred in the MRD for over a century. Production increased rapidly and then declined as reserves were depleted and fluid output was dominated by produced water (Figures 2 and 3). This is true for the overall production history and for individual fields that were active for $30-50$ years or more.

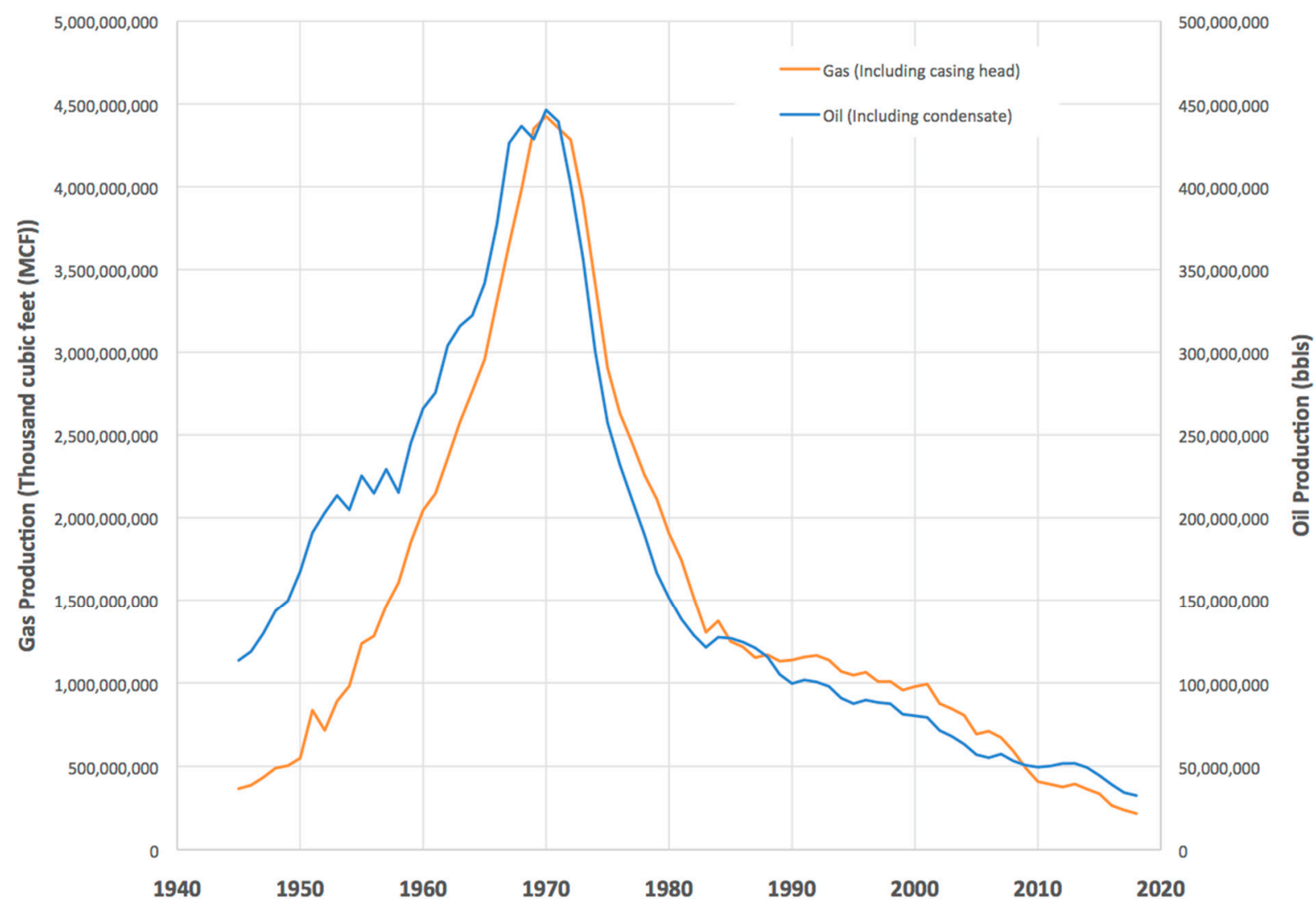

Figure 2. Annual oil and gas production in southern Louisiana between 1945 and 2019. Data source: (http://www.dnr.louisiana.gov/assets/TAD/OGTables/Table03.pdf).

Wetland loss in coastal Louisiana has been quantified $[19,24,25]$. Researchers have used different proxies of field development to correlate this land loss with specific oil and gas activities [26-29]. The authors of [30] reported the highest rates of wetland loss in the MRD correlated with peak hydrocarbon production (Figure 3). In [18] it was reported that the annual number of well drilling permits, a proxy for production, correlated with wetland loss rates (Figure 4). In this paper we investigate the factors contributing to these relationships. 
Annual fluid production vs rate of wetland loss, Louisiana delta plain

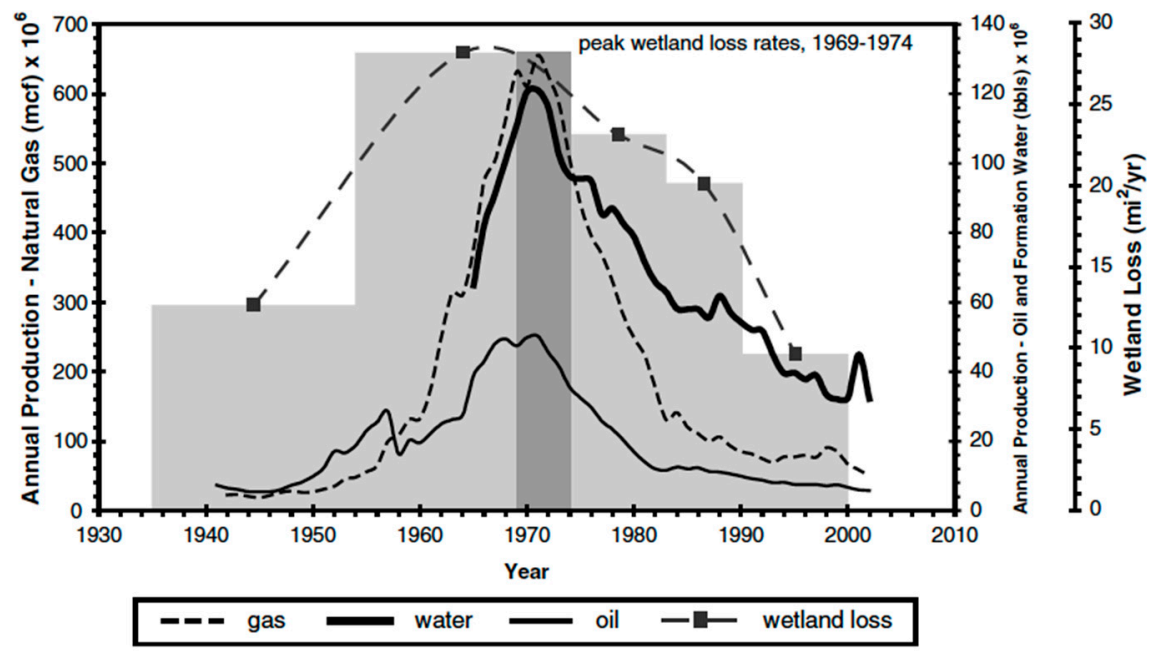

Figure 3. Composite histories of fluid production from oil and gas fields and wetland loss in south Louisiana. Production data from the Louisiana Department of Natural Resources and the PI/Dwights PLUS database [31]. Wetland loss values were determined by [32] and John Barras (unpublished data). These historical data, integrated across the delta plain, show close temporal and spatial correlations between rates of wetland loss and rates of fluid production [30]. Note that "water" in the legend refers to produced water.

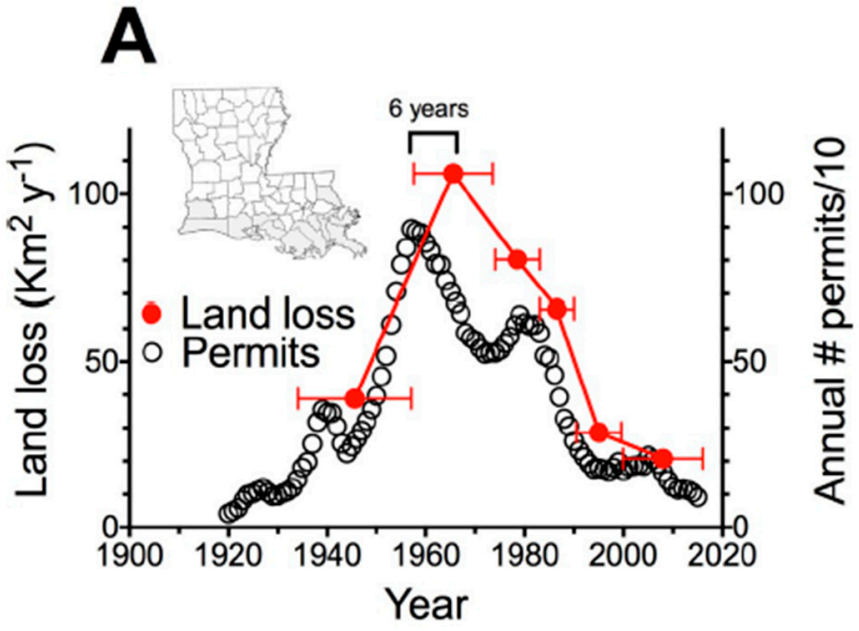

Figure 4. The number of oil and gas permits issued annually and land loss rates [18].

Although individual fields show a similar pattern of production history and wetland loss, they differ in some details as illustrated for four different field complexes (Figure 5) that produced O\&G over 4-6 decades. The Bully Camp and Madison Bay area had increased produced water development in the second half of their production history. Peak water production in the Bayou Rambio and DuLarge fields coincided with peak gas in this region that had relatively low oil capture. Water production was also high in the second half of the production history of this area. The pattern of water production in the Pointe au Chien study area was similar to gas production in the second half of the oil field life. In each example though, the production of oil, gas, and produced water varied over the field life-cycle, each field began, peaked, then gradually depleted over decades. All fields combine to yield the overall history of the coastal zone (Figures 2 and 3). All four fields illustrate the concept of a development cycle that includes a run-up to peak production followed by a gradual decrease to total abandonment. Individual fields and the aggregate of all fields follow a similar life cycle. These patterns have important implications for the impacts of hydrocarbon extraction on coastal ecosystems, especially wetlands, 
for three main reasons. First, dredging of canals leads to severe alteration of surface hydrology that impacts coastal wetlands. Second, extraction of fluids (oil, gas, and water) leads to changes in pore pressure that result in induced subsidence and fault activation. Third, accidental spills and intentional releases of oil and produced water cause toxicity stresses that degrade coastal ecosystems. These factors are discussed in more detail below, after which we show how cumulative and interacting impacts multiply the individual impacts.
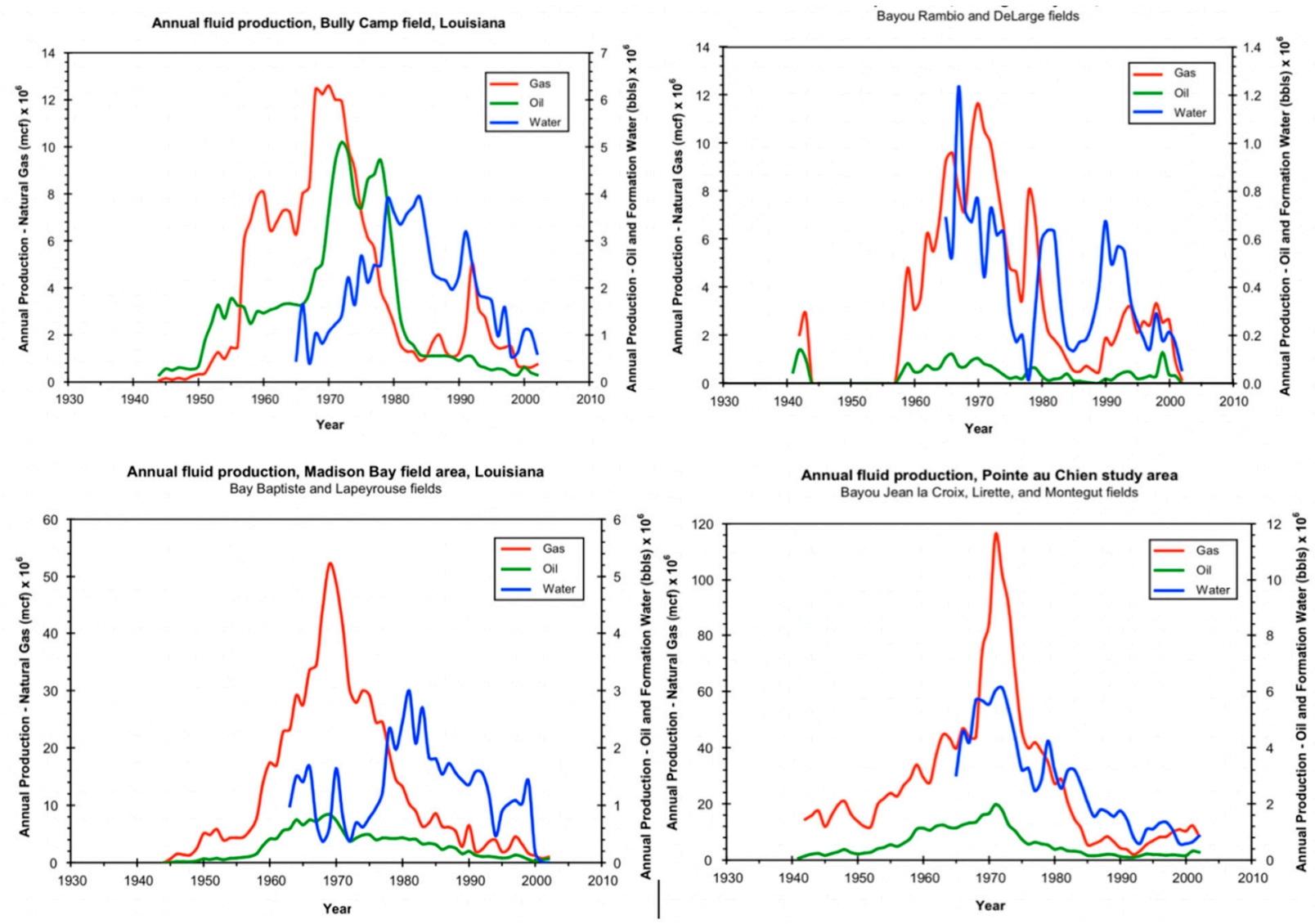

Figure 5. Production history of selected oil and gas fields in the Mississippi delta. Upper left-Bully Camp; upper right—Bayou Rambio and DeLarge fields; lower left-Madison Bay field area; lower right-Pointe au Chien study area [30]. Note that "water" in the legends refers to produced water.

\section{Patterns of Wetland Loss and Oil and Gas Activities}

From 1930 to 2010 about a quarter (about $5000 \mathrm{~km}^{2}$ ) of MRD coastal marshes were lost, mostly by conversion to open water [33,34] with two general patterns (Figure 6). Wetland loss has been pervasive across the coast with high loss near the mouth of the Mississippi River, in the Barataria and Terrebonne basins, and in the Chenier Plain. Two areas stand out with much less loss. One is the central coast that receives input from the Atchafalaya River, which carries about a third of total Mississippi River discharge, that flows into shallow bays and wetlands over a wide arc along the central Louisiana coast. The other zone is on the northeastern flank of the delta in the seaward reaches of the Pontchartrain estuary. 


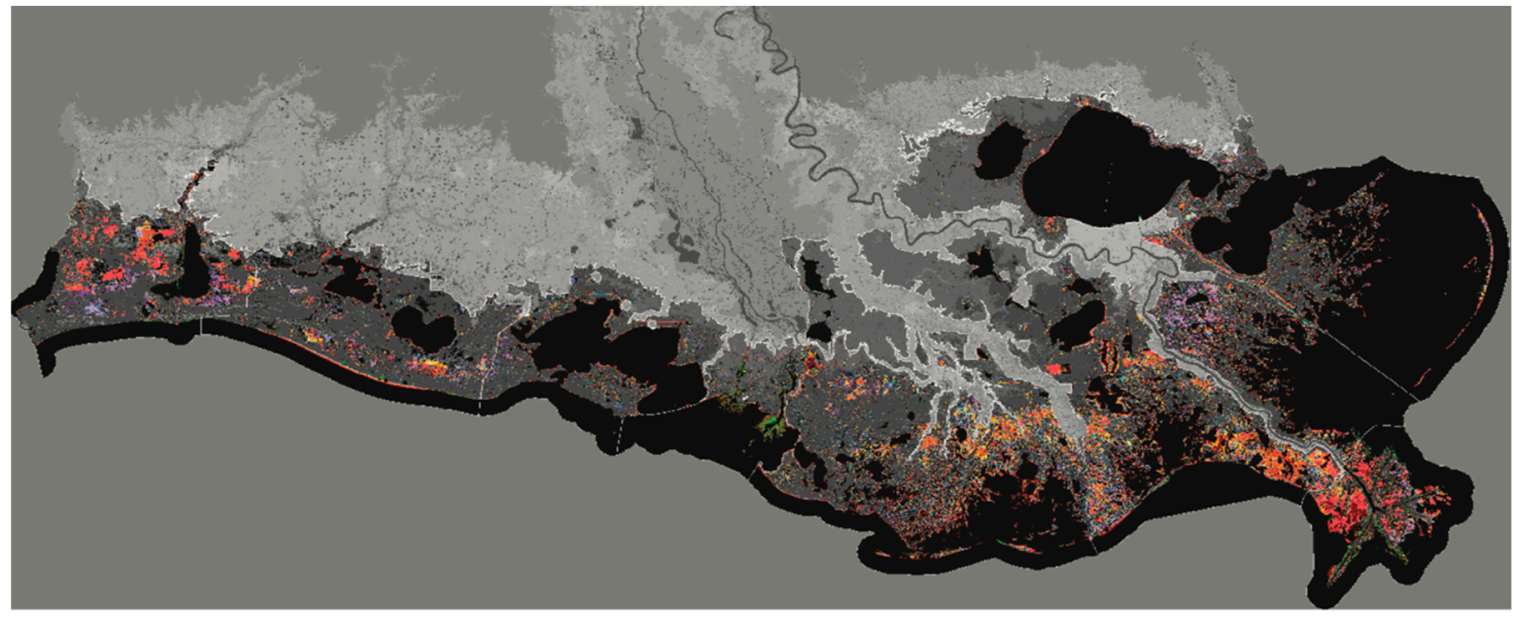

Figure 6. Wetland loss in coastal Louisiana from 1932 to 2016. Red and yellow areas have high land loss rates. Note that land loss is low in the central coast and in the northeastern flank of the delta. (Source: $[33,34]$ The map can be downloaded at https://pubs.usgs.gov/sim/3381/sim3381.pdf for detailed examination of specific areas of change. See also https://pubs.er.usgs.gov/publication/sim3381).

A number of studies have discussed the causes of wetland loss and addressed the role of O\&G activities in this loss (Table 1). O\&G activities reduce forces leading to wetland sustainability (e.g., sedimentation, accretion, vegetation biomass production) and enhance forces leading to deterioration (e.g., increased subsidence, saltwater intrusion, vegetation decline, toxicity stresses). O\&G impacts on wetlands are both direct and indirect. Direct loss is due both to canal dredging and spoil placement, while indirect impacts include alteration of surface hydrology, induced subsidence, and introduction of toxic substances. Direct impacts are reported to have caused between $6 \%$ and $70 \%$ or more land loss while indirect impacts have caused between $20 \%$ and $80 \%$ or more of wetland loss (Table 1).

Table 1. Estimates of the percentage of wetland loss caused by all oil and gas activities (overall) or by direct or indirect impacts of oil and gas activities.

\begin{tabular}{|c|c|c|c|c|c|}
\hline Location & Time Period & $\begin{array}{c}\text { Overall } \\
\text { Impacts (\% } \\
\text { Wetland Loss) }\end{array}$ & $\begin{array}{l}\text { Direct Impacts } \\
\text { (\% Wetland } \\
\text { Loss) }\end{array}$ & $\begin{array}{c}\text { Indirect } \\
\text { Impacts (\% } \\
\text { Wetland Loss) }\end{array}$ & Source \\
\hline Coastal Louisiana & 1931-1967 & & 69 & & [35] \\
\hline Coastal Louisiana & & 45 & & & [36] \\
\hline Coastal Louisiana & & & $10-69$ & & [37] \\
\hline Coastal Louisiana & & & 10 & up to 80 & [38] \\
\hline Coastal Louisiana & 1955-1978 & & 10 & $48-97$ & [39] \\
\hline $\begin{array}{l}\text { Mississippi River } \\
\text { Deltaic Plain }\end{array}$ & 1955/56-1978 & & $25-39$ & & [40] \\
\hline Coastal Louisiana & 1932-1990 & $\begin{array}{l}\text { Majority of } \\
\text { losses due to } \\
\text { canals }\end{array}$ & & & {$[18,26,27]$} \\
\hline Coastal Louisiana & 1955-1978 & $20-60$ & $14-16$ & $20-60$ & [16] \\
\hline Coastal Louisiana & 1955-1978 & & 16 & & [41] \\
\hline Coastal Louisiana & 1955-1978 & & 6.6 & & [42] \\
\hline Coastal Louisiana & 1955-1978 & & 16 & $30-59$ & [43] \\
\hline Breton Sound & 1933-1990 & 68 & & & [9] \\
\hline Barataria Basin & 1933-1990 & 72 & & & [9] \\
\hline Mermentau Basin & 1933-1990 & 35 & & & [9] \\
\hline $\begin{array}{l}\text { Mississippi River } \\
\text { Deltaic Plain }\end{array}$ & 1930-1990 & 33.2 & 10.8 & 22.4 & {$[24,25]$} \\
\hline
\end{tabular}


Wetland loss patterns are generally similar to temporal patterns of production (Figure 7). The different studies were done using different methods and represent different conceptualizations of the delta and sub-areas sampled. Regardless of the proxy used to describe the oil and gas life-cycle, the relation to land loss is unmistakable. The rates of land loss differ because they are for different areas (e.g., total coast vs. deltaic and Chenier plains) and for different time periods and the study methods, though similar, are not the same [32,34,44]. Peak loss occurred generally between 1960 and 1980. The curve for total O\&G production is sharper than that of land loss likely because of delayed impacts of $O \& G$ as well as other causes of land loss (e.g., isolation from riverine input, edge erosion, hurricane impacts).

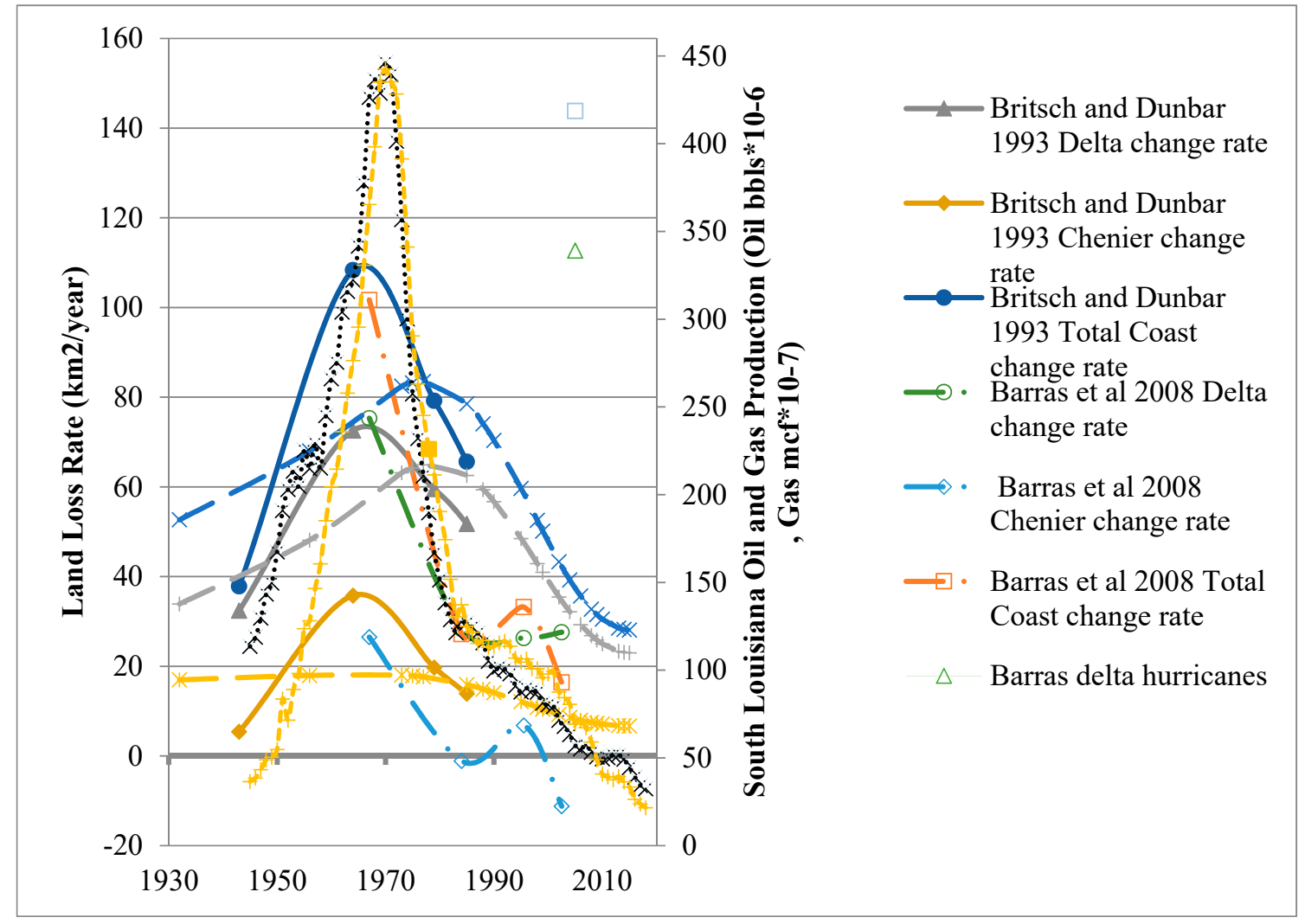

Figure 7. Oil and gas production and land loss studies for coastal Louisiana. Loss values are from $[32,34,44]$ where rate values represent an average over the time interval shown. Production data are from Louisiana Department of Natural Resources. These historical data show close temporal and spatial correlations between rates of wetland loss and rates of hydrocarbon production.

\section{Indirect Impacts of Oil and Gas Exploration and Production on Coastal Louisiana Wetlands}

\subsection{Alteration of Surface Hydrology Due to Canal Dredging and Spoil Placement}

MRD wetlands are dependent on sheet flow for exchange of water, sediments, and nutrients to sustain wetland health. Unimpeded wetland hydrology facilitates alternating flooding and draining of wetlands. Canals and spoil banks are linear and intersecting, and spoil banks are higher in elevation than surrounding wetlands and normal high tides $[4,9,15,45]$. Placement of dredge spoil impounds wetlands, reducing or eliminating surface water exchange and tidal influence, reducing sediment deposition onto wetlands, impeding the exchange of materials (e.g., nutrients, sediments, organisms) between semi-impounded marshes and the surrounding marsh, and increasing inundation duration while decreasing inundation frequency $[2,4,16,46-50]$. Spoil banks trap water, increasing water logging and decreasing drainage, sediment accretion, and vegetation productivity (Figure 8) $[4,15,16,19,46,48,51-63]$. 
As surface flow is minimized by spoil banks, water may only be introduced into impounded wetlands when water levels are elevated during frontal passages or major storms.

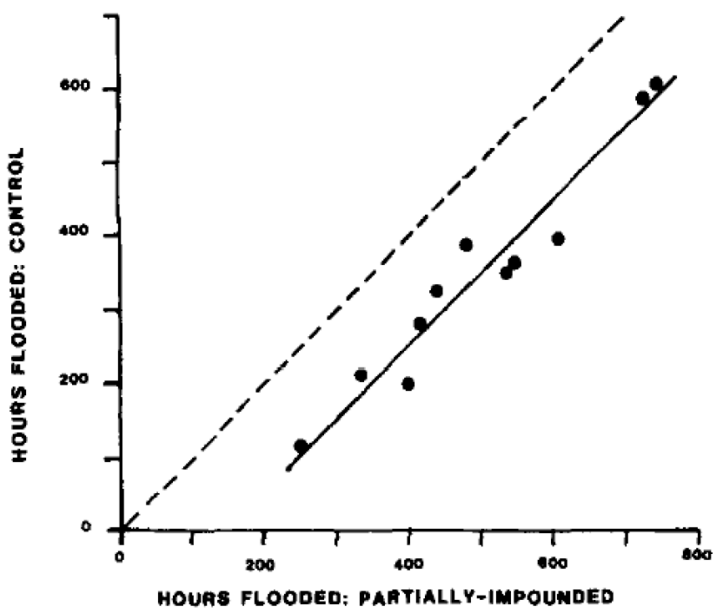

Figure 8. Total hours flooded, for one month, at a reference marsh with a natural berm and a partially impounded area where about $75 \%$ of the natural berm had been replaced by a dredged canal spoil bank, Golden Meadow oil and gas field south of New Orleans, LA [52]. The dashed line shows what the relationship would be if there were no partial impoundment.

Due to spoil banks, accretion in un-impounded marshes may be up to five times higher than that in impounded marshes [3,57,61,64-67]. Canals also promote saltwater intrusion into wetlands previously isolated from direct exchange with higher salinity waters $[2,4,27,47,48,68-71]$. Increases in salinity cause changes in vegetation composition and reduced productivity and/or death of fresh and low salinity marsh species and lead to formation of open water [53,71-73]. Introduction of saltwater increases sulfate concentrations, which can be reduced to sulfides in anaerobic soils, that stresses and causes mortality to low salinity wetland vegetation [73] and rapid decomposition and collapse of soil organic matter and soil structure peats [74]. Reduced vegetation productivity and vegetation death exacerbate land loss because plant roots bind soils and increase soil strength. When roots die, the wetland rapidly loses elevation and is more vulnerable to erosion [74,75].

Over time, canals widen as a result of spoil bank undercutting, erosion, and collapse causing additional wetland loss $[45,46]$. Localized subsidence along pipeline canals occurs along the flanks of spoil banks when the weight of the spoil depresses the surface of the marsh and leads to the formation of linear ponds behind the spoil banks due to subsidence from the weight of the spoil, trapping of water at the base of spoil banks and blocking of sediment input [76]. The authors of [77] documented soil compaction beneath spoil banks created more impenetrable soils that reduced ground water movement. These processes isolate the wetland behind the spoil bank from both above- and belowground water exchange.

O\&G canals are deep, straight channels while natural waterways are primarily shallow and sinuous tidal channels [4]. As canal density increases in an area, the density of natural channels decreases because canals preferentially capture water flow from natural channels (Figure 9) [37,52] in a process termed 'channel theft', because deep, straight canals transport water more efficiently than natural shallow and sinuous channels [50]. 


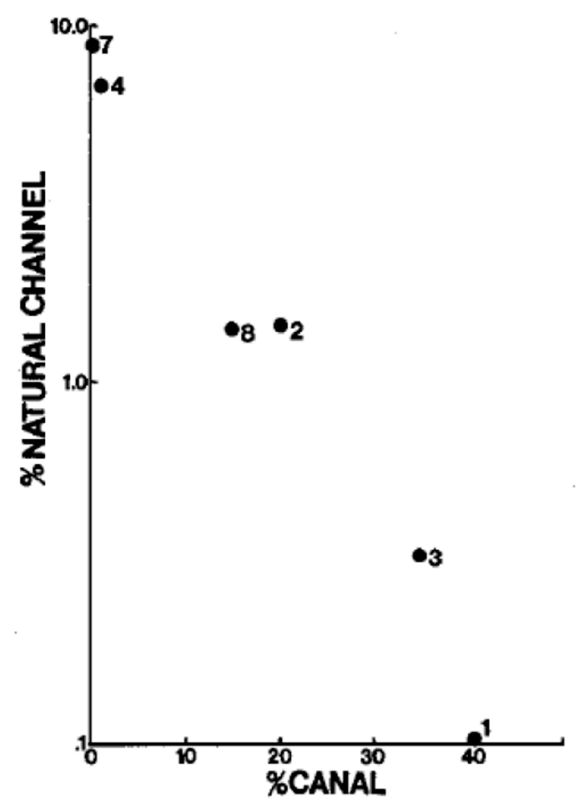

Figure 9. The relationship between canal density and the density of natural channels. The data are averages of replicate $1-\mathrm{km}^{2}$ grids (numbers shown by symbol) in the region of Leeville, LA, a saline marsh area [37].

Once dredged, spoil banks are not permanent features and have a life cycle of their own. They disappear over time due to compaction, subsidence, sea-level rise, and erosion. Spoil banks protect remnant marsh from wave erosion and as spoil banks disappear remnant marsh can be lost due to wave attack, leading to further wetlands loss. In Figure 10, subaerial land that disappeared between the two mapping dates (center panel in Figure 10) in the Leeville Field includes both spoil banks and marsh.

As O\&G canals are so pervasive, it has been suggested that canals are responsible for practically all wetlands loss. For example, the authors of $[18,27]$ plotted land loss from 15 -min quadrangles against canal density and concluded that land loss was directly related to the percent of canals in each map, indicating that almost all land loss was related to canals (Figure 11). However, in [5] and [9] the authors showed that this approach is flawed because it statistically relates all land loss in 15-min quadrangles (which cover about 66,000 ha) to canal density in the quadrangle even when it is neither spatially or functionally related to land loss patterns. Additionally, as we discuss below, induced subsidence causes land loss but is not functionally related to surface alterations in hydrology. In addition, toxic stress due to spilled oil and produced water cause vegetation stress and mortality. However, altered hydrology, induced subsidence, and toxic compounds interact synergistically and cause wetland loss as indicated by the interactions demonstrated in the Leeville field (Figure 10). 


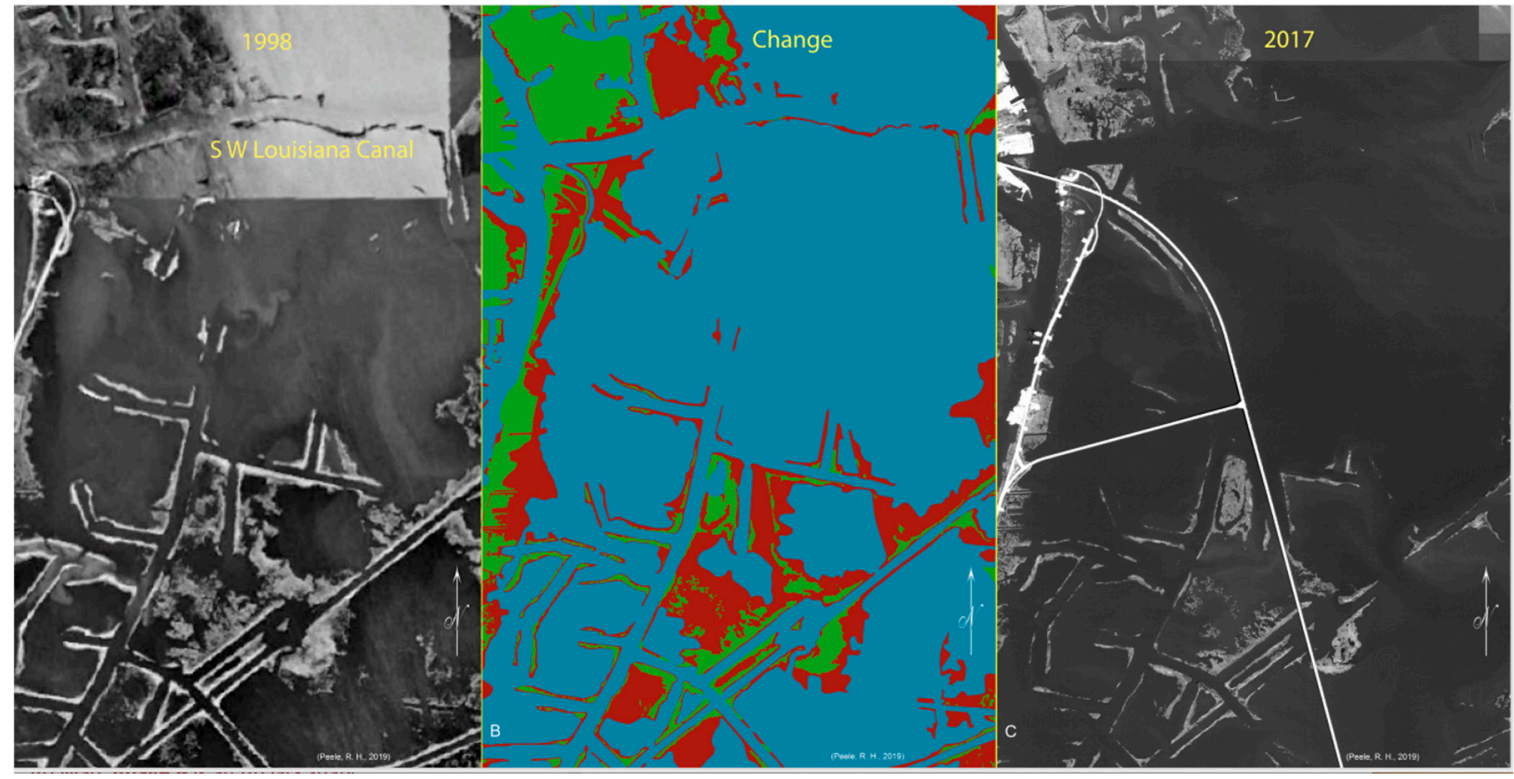

Figure 10. Aerial imagery of a portion of the Leeville oil and gas field in southern Louisiana showing the disappearance of spoil banks and marsh between 1998 and 2017. Bayou Lafourche is in the upper left in each of the images [5]. Areas depicted in red in image B disappeared between the two dates. Red linear strips are spoil banks that disappeared. Green shows subaerial land, both spoil banks and marsh, that was still present in 2017. The Southwest Louisiana Canal at the top of image A was dredged in the late 19th century. In 1998, some spoil banks along the canal were still present, but by 2017 they had disappeared. Louisiana highway 1 is shown at the upper left in image A. By 2017, a new, elevated highway was constructed (white lines in Image C). The width of images is approximately $2.8 \mathrm{~km}$.

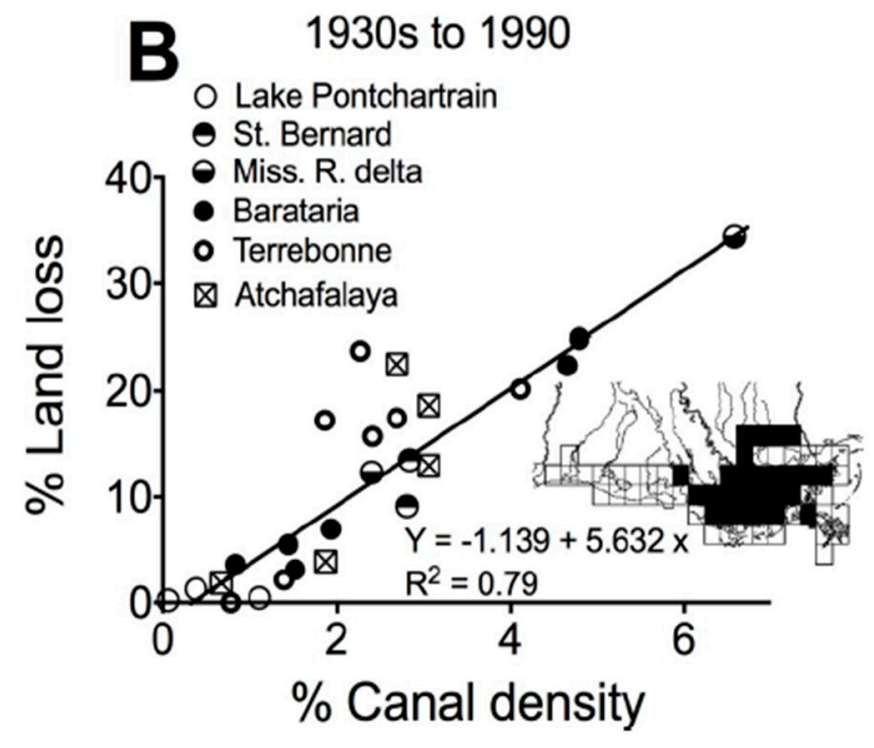

Figure 11. The land loss rate from the 1930s to 1990 and canal density in 15-min quadrangle maps. The authors of [18] concluded that this demonstrates that most wetlands loss is due to canals. This is incorrect, however, because of the large size of 15-min quadrangle maps and other causes of land loss due to induced subsidence and toxic stress.

\subsection{Oil and Gas Production Induced Subsidence}

Oil, gas, and brine extraction depletes the hydrocarbon reservoir, often precipitously, resulting in pressure drop, compaction, and fault activation (usually reactivation); and this change at depth translates upward, manifesting at the surface as subsidence and faulting. That is, without pressure 
support the depleted reservoir collapses, and the pressure difference at the nearby associated fault plane nucleates slippage there $[4,20,28,30]$, leading to a subtle, and sometimes dramatic, overprint integrated with other O\&G related processes. Observations generally confirm the relationship between fluid production and subsidence in coastal Louisiana: for example, wetland loss is typically higher in the vicinity of oil and gas fields [9,20,29,78-83]. On the coastal Chenier Plain, the authors of [83] suggested that paleo-sea level elevations, vertically offset by $0.5-1 \mathrm{~m}$ on a transect near the area of maximum oil and gas production, were influenced by this production. Local rates of measured subsidence in oil and gas fields in south central Louisiana (often more than $20 \mathrm{~mm} /$ year) were much higher than regional rates in the Mississippi River Delta (about $10 \mathrm{~mm} /$ year) [84]. In [30] the authors analyzed releveling surveys, remote images, subsurface maps, stratigraphic sections, and hydrocarbon production data in relation to wetland loss for the Terrebonne-Lafourche basins and found that the highest rates of subsidence coincided with the location of oil and gas fields (Figure 12) [30]. This study also showed that subsidence rates were greater in the later epoch (1982-1993) than the earlier (1965-1982); that is, subsidence accelerated late in the cycle of O\&G production. In [20,30,84] it was concluded that these rapid changes were likely caused by induced subsidence and fault reactivation due to oil and gas activity.

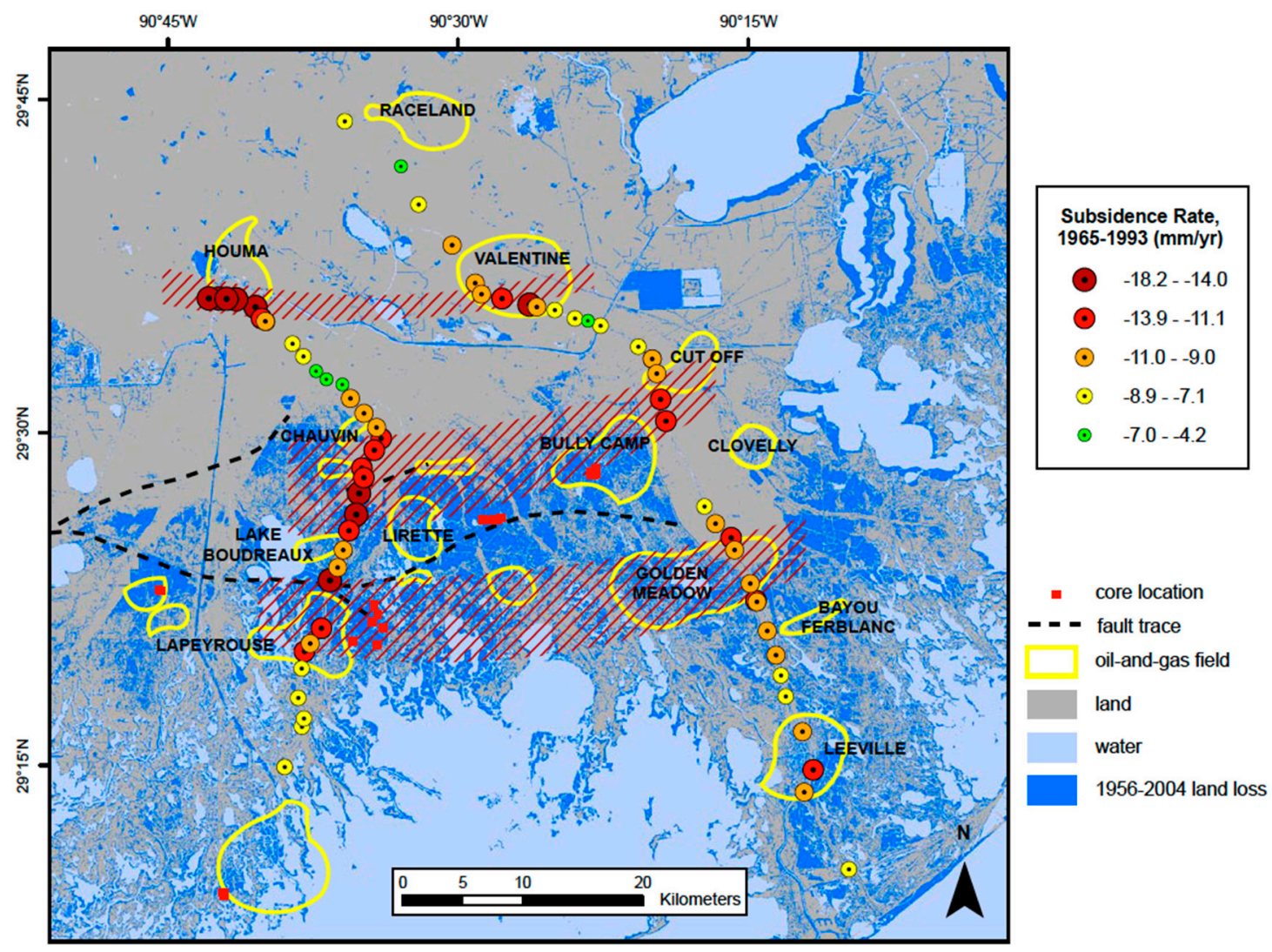

Figure 12. Map showing average subsidence rates between 1965 and 1993 in south Louisiana. Areas of highest subsidence rates (>12 mm/year; hatched pattern) correlate closely with locations of oil and gas fields. Lowest average subsidence rates are located between major producing fields [30].

Elevation change related to faulting in the MRD is often marked by an arcuate scarp separating marsh and water [85], while subsidence related to a reservoir's compaction is spread over and beyond the production area (up to kilometers away from the producing wells) [20]. Subsidence involved with O\&G fields typically begins around the time of peak production [84], and continues for an extended time as the field is depleted, often decades after peak production $[29,79,86]$, though it too reaches an ultimate limit $[79,84]$. 
The Mississippi Delta is particularly susceptible to subsidence and faulting since rapid deposition of sands and clays has created a weak, metastable situation that responded from early in its geologic history with "landslide-like" faulting (down to the coast listric normal faulting) parallel to the coast, and that faulting has progressed upward as deposition continued - that is, growth faulting [14,87-89]. The sedimentary section developed so rapidly that there was little time for consolidation, cementation, or in many cases, normal pressure equilibration. At the same time, these faults and related rollover anticlines on their downthrown side, formed hydrocarbon traps, the basis for many of the present-day O\&G fields on the delta (Figure 13). To add complexity, the low density, easily deformed Louann salt layer that began near the base of the geologic section flowed upward in various geometries, creating salt domes dragging up steeply tilted beds, faults, and anticlinal features that became hydrocarbon traps as well. Growth faults in the delta move episodically over their lifetime, and along segments a few kilometers in length (e.g., [90]). Over the cycle of MRD petroleum development, a number of these growth faults related to oil and gas fields have been reactivated, with consequent displacement and surface subsidence on the fault downthrown side. The mechanism of reactivation along these growth faults is expedited by a poroelastic reduction of horizontal confining stress, which occurs as a result of the fluid withdrawal and consequent pore pressure decrease [91,92]. That is, faults related to MRD O\&G fields that break the surface today are mostly reactivated growth faults involved with the reservoirs below—reservoirs that these faults created in the first place.

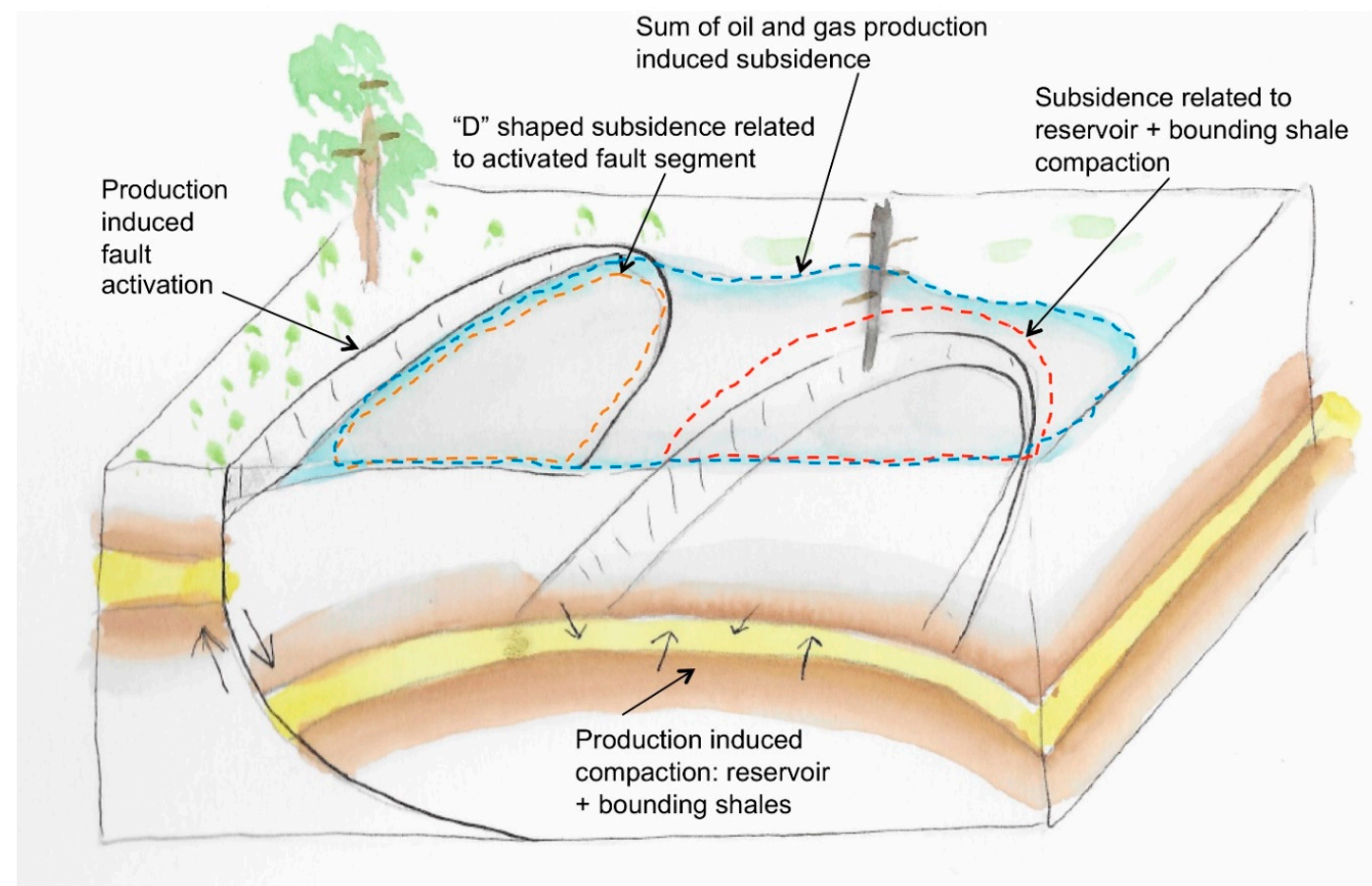

Figure 13. Typical Mississippi River Delta oil and gas reservoir, a rollover anticline on the downthrown side of a down-to-the-coast normal fault. Oil, gas, and water production affects the subsurface in and around the producing reservoir. The depletion process leads to production induced fault activation, reservoir compaction with additional compaction of bounding shales as shown in the subsurface. The surface manifestation of these subsurface changes is shown as a composite of land loss on the downthrown side the activated fault plus subsidence over the compacted oil, gas, and water producing reservoir.

The mechanism of O\&G subsidence is involved with the collapse of the reservoir itself. Subsidence happens when production of oil, gas, and water (and sometimes sand) reduces reservoir sand pore pressure to the point where it can no longer support the overburden [93]. Thus, the delta's young, often poorly consolidated reservoir sands, sandwiched between shales, often undergo compaction 
with production drainage and this deformation is transferred to the surface as a subsidence bowl form. The authors of [94] modeled this reservoir compaction and surface deformation process using the concept of a nucleus-of-strain (the impacted reservoir), together with an elastically deforming half-space (the geologic section above), spreading the effect and reducing the displacement to produce a halo-like effect in and around the O\&G field. In [79] the authors used this concept along with 1982-1993 epoch releveling at the Leeville, Golden Meadow, Cut Off, and Valentine fields and the authors of [95] modeled the Lapeyrouse field (Figure 12). At Lapeyrouse, modeling matched the measured releveling when a reactivated down-to-the-coast growth fault was added to the deformation of the compacted disc reservoir sand. This reservoir compaction subsidence process is found in fields along the Louisiana coast and often acts in concert with O\&G field related faulting.

In [29] the authors considered the extended timeframe of subsidence where displacement related to depleted O\&G fields did not stop as the production cycle ended, but accelerated significantly for decades. As shown in Figure 14, this study indicates (a) greater subsidence over traversed O\&G fields for each epoch (panels A and B), (b) increased subsidence rates (accelerated subsidence) in the later epoch (panel C), and (c) areas of greatest subsidence and rates likely related to fault displacement.
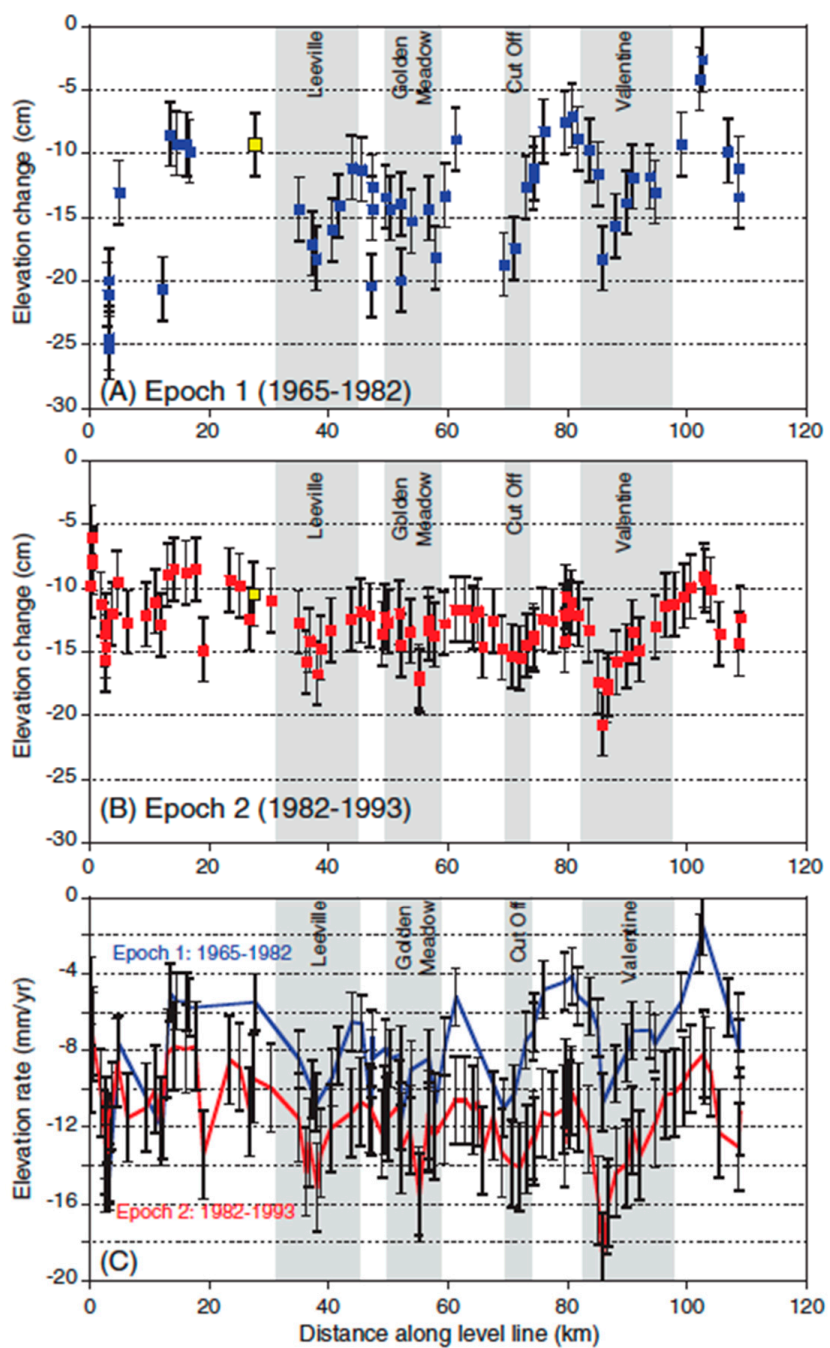

Figure 14. Elevation changes during epoch 1 (1965-1982; A) and epoch 2 (1983-1993; B), and the rates of subsidence in the two epochs $(\mathbf{C})$. Over the entire transect, subsidence rates were greater in epoch 2 than in epoch 1. The yellow squares in (A) and (B) indicate an arbitrarily selected reference station approximately $8 \mathrm{~km}$ south and outside of the projected Leeville (see Figure 10) to estimate the magnitudes of local production-related subsidence signals [29]. 
While post production time-dependent subsidence is intuitively expected due to factors such as slow dissipation of pore pressure in the reservoir (e.g., [96]), and time-dependent creep in the reservoir [97], this subsidence typically happens over only a few years, not decades after and not with acceleration. The authors of [29] considered the role of the bounding shale above and below the sand reservoir itself (Figure 15), and modeled compaction in the Valentine field (Figures 12 and 14) in two stages, the first being poroelastic compaction of the reservoir sand during active production, followed by the time-delayed compaction resulting from slow poroelastic and viscoplastic compaction of the low-permeable bounding shale as included pore water slowly drained into the depleted sand.

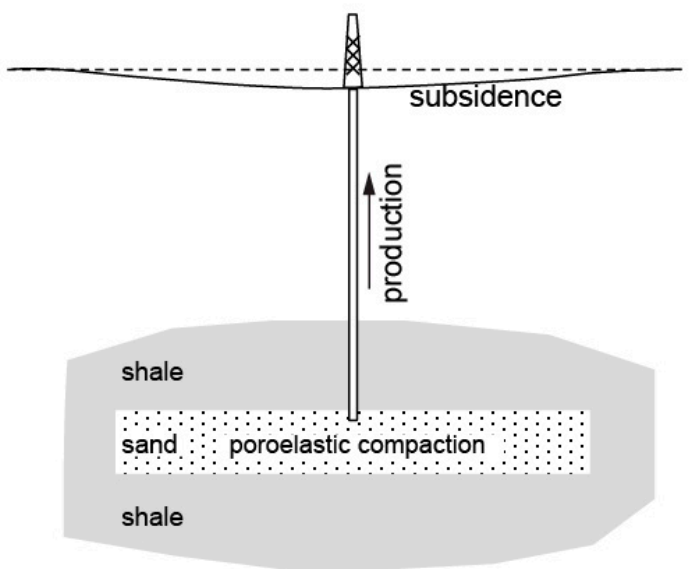

(a) during production

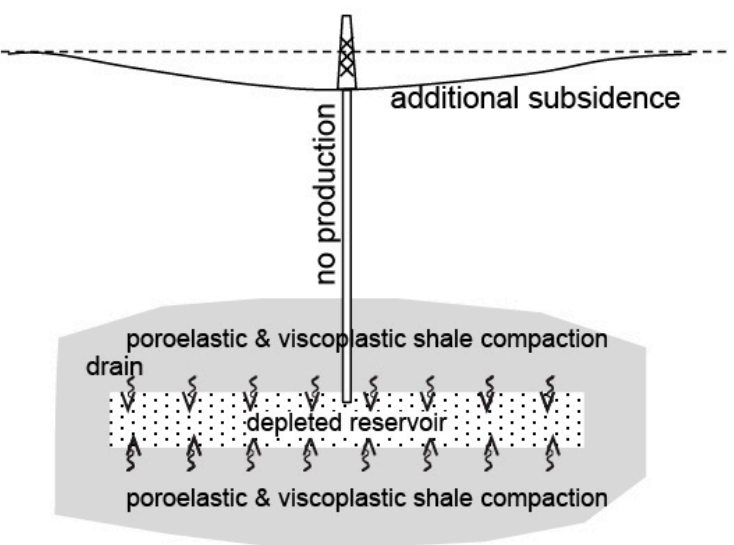

(b) after depletion

Figure 15. A simple compaction model of sand reservoir embedded with surrounding shale. It is assumed that during production stage, pore pressure depletion in a sand reservoir induces poroelastic compaction, and after depletion, a slow decrease in pore pressure in the bounding shale induces shale compaction in two independent rheological modes (poroelastic and viscoplastic) (modified from [29]).

Compaction that occurs in reservoir-bounding shales is often evidenced by wellbore problems in overburden formations during and after production, such as casing damage and even shear (e.g., [98]). These studies and others matching displacement measurements and mathematical modeling of causality mechanisms, confirm the importance of oil and gas field induced subsidence and faulting. In summary, fault reactivation and reservoir compaction lead to induced subsidence at the surface that reflects both. The interaction of these elevation change mechanisms with oil and gas field development is an important part of land loss in the MRD.

\section{Toxic Impacts of Produced Water and Spilled Oil}

Produced water from O\&G fields is brought to the surface during crude oil and natural gas extraction and, prior to the USEPA banning surface discharge of produced water in 1992, an estimated 2 million barrels per day were discharged into Louisiana coastal wetlands from nearly 700 sites [99]. It is by far the largest volume byproduct or waste stream associated with O\&G extraction and is about 10 times more toxic than oil [100]. The fluid generally includes a mixture of either liquid or gaseous hydrocarbons, high salinity water, radioactive materials, dissolved or suspended solids, solids such as sand or silt, and injected fluids and additives associated with exploration, drilling, and production activities (Table 2) [101,102]. 
Table 2. Common components of produced water resulting from oil and gas production [103].

\begin{tabular}{|c|c|}
\hline Category & Constituent \\
\hline Metals & $\begin{array}{c}\text { Aluminum, antimony, arsenic, barium, boron, cadmium, gold, } \\
\text { iron, mercury, chromium, copper, lead, zinc, nickel, platinum, } \\
\text { silver, strontium, tin, magnesium, molybdenum, titanium, } \\
\text { thallium, vanadium }\end{array}$ \\
\hline Naturally occurring radioactive materials & Radium-226, radium-228 \\
\hline Monocyclic aromatic hydrocarbons & $\begin{array}{l}\text { Benzene, benzoic acid, chlorobenzene, di-n-butyl phthalate, } \\
\text { toluene, ethlybenzene, isopropylbenzene, n-Propylbenzene, } \\
\text { p-chloro-m-cresol, xylenes }\end{array}$ \\
\hline Polycyclic aromatic hydrocarbons & $\begin{array}{l}\text { Acenaphthene, anthracene, benzo(a)anthracene, cyrsene, } \\
\text { dibenzothiophenes, fluoranthene, flourene, napthalene, } \\
\text { benzo(a)pyrene }\end{array}$ \\
\hline Miscellaneous organic chemicals & Phenols, bis(2-ethylhexyl)phthalate, oil and grease \\
\hline Miscellaneous other components & $\begin{array}{l}\text { Calcium, potassium, radon, sodium chloride, total dissolved } \\
\text { solids, ammonia, bromides, sulfates, sulfides }\end{array}$ \\
\hline
\end{tabular}

Several factors determine the fate and effects of produced waters in coastal environments including the volume and composition of the discharge and the hydrologic and physical characteristics of the receiving environment [22,104]. In many cases, oil field brine was discharged directly to wetlands and surface waters [105]. Energetic storms can mix the water column and advect produced water into marshes where it can significantly damage vegetation. Spills may also impact wetlands. In [106] accidental brine spills between 1990 and 1998 were studied, and a total of 567 brine spills were reported to LDEQ. In sites where produced water was spilled, acute and chronic exposure affected the vegetation. The study author documented ecological impacts ranging from minor vegetation damage to the destruction of hundreds of ha of wetlands. Many wetlands where a single spill had occurred had not recovered up to 10 years later and most of the wetlands with chronic exposure were no longer vegetated and some had converted to open water. In [105] the formation of new ponds where produced water was being discharged was documented and the authors of [23] reported that half of the Spartina alterniflora exposed to $120 \mathrm{mg} / \mathrm{L}$ of oil and grease, which is the norm for produced water, died within 30 days.

Salinity of produced water ranges from a few psu to up to 300 psu [21,22,102,103]. High salinity leads to the death of most plants and has been linked to wetland loss [105]. In Cameron Parish, Louisiana, north of Black Lake and the Hackberry O\&G fields, thousands of ha of sawgrass marsh were killed due to discharge of produced water and the area subsequently converted to open water $[107,108]$. Naturally occurring radioactive material (NORM), primarily radium-226 and radium-228, is present in much of the produced water in the Gulf of Mexico [109,110]. The authors of [104] reported total radium activities ranged from 304 to $2312 \mathrm{dpm} / \mathrm{L}$.

Hydrocarbons are also present in produced water, both in dissolved and dispersed (oil droplets) form that can interact with the benthic community [103]. Dispersed oils can also rise to the surface and interfere with the transfer of oxygen from the atmosphere into the water, coat marine mammals, birds and fish, and have direct toxic action on some organisms [111]. Whole effluent toxicity assessments have reported high toxicity levels of produced water [21,112]. Produced water has been shown to reduce abundance of benthic macroinfaunal communities in wetlands receiving discharge $[21,99,104,112]$ often at distances of hundreds of $m$ from discharge sources. [112]. The presence of high concentrations of hydrocarbons in sediments near discharge sites indicates long-term accumulation and resistance to degradation $[21,22]$.

In [4] the authors reviewed the ecological impacts of O\&G development on coastal ecosystems in the Mississippi delta. Oil spills have generated significant impacts due to the toxicity of spilled oil. Effects on plant communities include disruption of plant-water relationships, direct impacts to plant metabolism, toxicity to living cells, and reduced oxygen exchange between the atmosphere and the soil. Effects on consumers include growth inhibition, reduced production, altered metabolic systems, 
and biomagnification of hydrocarbon compounds. The combination of these factors increases plant stress and plant death.

\section{Interactive, Cumulative, and Indirect Impacts of Oil and Gas Impacts}

Each of the three types of oil and gas activity (alteration of surface hydrology, induced subsidence, and production of toxic contaminants) causes significant impacts. However, when the effects of all three activities interact in cumulative and indirect ways, the impacts are much greater.

In Figure 16, the impacts of each type of activity are shown separately. The direct effect of induced subsidence is a loss of surface elevation due fault activation and/or compaction of subsurface sediments due to fluid removal. Loss of surface elevation leads in turn to stressed wetland vegetation, lower productivity, and ultimately vegetation death and wetland loss.

Surface hydrologic alteration due to canals and spoil banks also leads to a loss of surface elevation due to a cascading series of impacts as shown by the relationships in Figure 16. Deep straight canals cause the deterioration of natural tidal channels and changes in regional hydrology and saltwater intrusion. Spoil banks block tidal flooding of marshes and lead to increased inundation of marshes as well as reduced sediment and nutrient input to marshes. These impacts stress marshes so that productivity is lower and organic soil formation is reduced. The combination of lower sediment input and lower organic soil formation causes higher shallow subsidence and ultimately to vegetation death. Saltwater intrusion and vegetation death lead to collapse of the soil column due to rapid decomposition of soil organic matter.

Toxic impacts are due to oil spills and produced water discharge which contains very high salinity brines and a variety of toxic materials. These stress vegetation and cause wetland mortality and collapse of marsh soils leading to loss of elevation.

Thus, all three types of impacts lead to stressed wetland vegetation, loss of elevation, and vegetation death. The cumulative and indirect impacts are much greater than for individual impacts acting independently. These interact with a range of environmental forcings such as lack of riverine input, sea-level rise, and hurricanes to exacerbate wetland loss even further. For example, wetland loss in the region of the central coast impacted by Atchafalaya River discharge is much lower than most of the rest of the coast even in areas impacted by $O \& G$ activity $[74,113]$. The net effect is that $O \& G$ activities make wetlands more susceptible to other forcings that negatively affect wetlands.

Such cumulative and indirect impacts due to $O \& G$ production are evident when images of oil fields are viewed over time. The Venice Salt Dome in Plaquemines Parish and the Bully Camp oil field in Terrebonne Parish are just two of hundreds of examples of wetland disappearance over time in coastal Louisiana (Figures 17 and 18). In these two fields, pre-oil and gas activity maps show the presence of small natural levee ridges and extensive unbroken marsh. In both fields, the 1950s maps show canals and spoil banks but without significant marsh loss. Over time, marsh loss expands to cover almost the entire area of the field and spoil banks begin to disappear as they subside below water level. The widespread loss of wetlands is due to such cumulative and interacting effects of surface alterations in hydrology, induced subsidence, and toxic effects. 

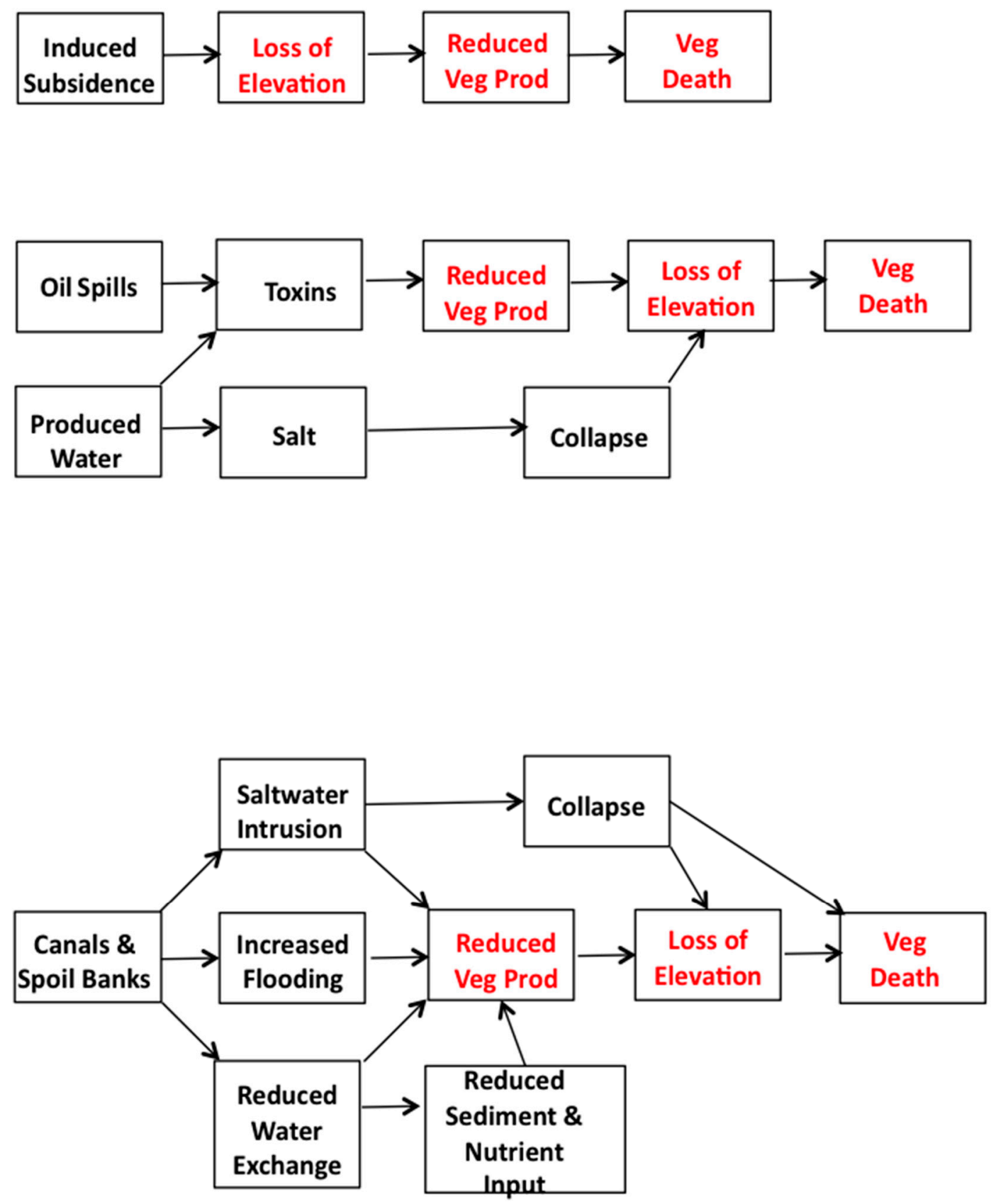

Figure 16. Diagram showing the three general types of impacts from oil and gas activity-induced subsidence, toxicity effects, and altered surface hydrology due to canals and spoil banks. The impacts of these activities are shown separately, and impacts shown in red are common to all three activities. As reduced vegetation productivity, loss of elevation, and vegetation death can result from all three activities, there are pervasive cumulative and indirect impacts that result in overall greater impacts on coastal ecosystems, especially, that would result from the impacts acting separately. 


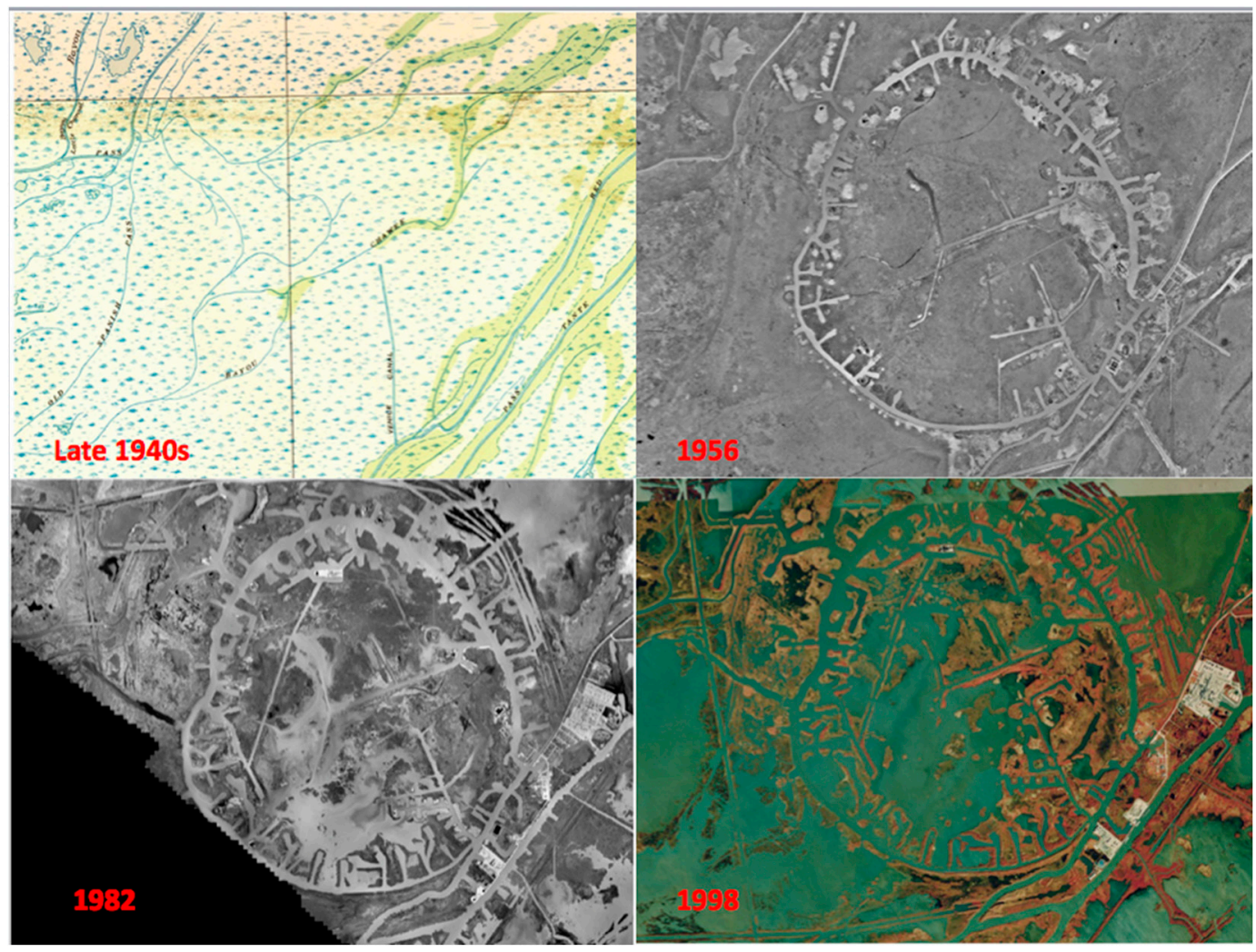

Figure 17. Images of hydrologic changes and wetland loss in the Venice field, Plaquemines Parish, Louisiana over time. This oil and gas field has been termed the "wagon wheel" because of the circular canals and spoil banks that outline the salt dome around which oil and gas containing formations were located. Note that wetland loss occurs both in the vicinity of the canals as well as throughout the area of the field. In addition to wetland loss, many of the spoil banks have subsided below water level and are no longer visible. The green highlighted channels in the 1940s are minor distributary ridges that both conveyed water and were a barrier to horizontal flow perpendicular to these ridges. (Images from USGS topographic maps (late 1940s) and Google Earth). 


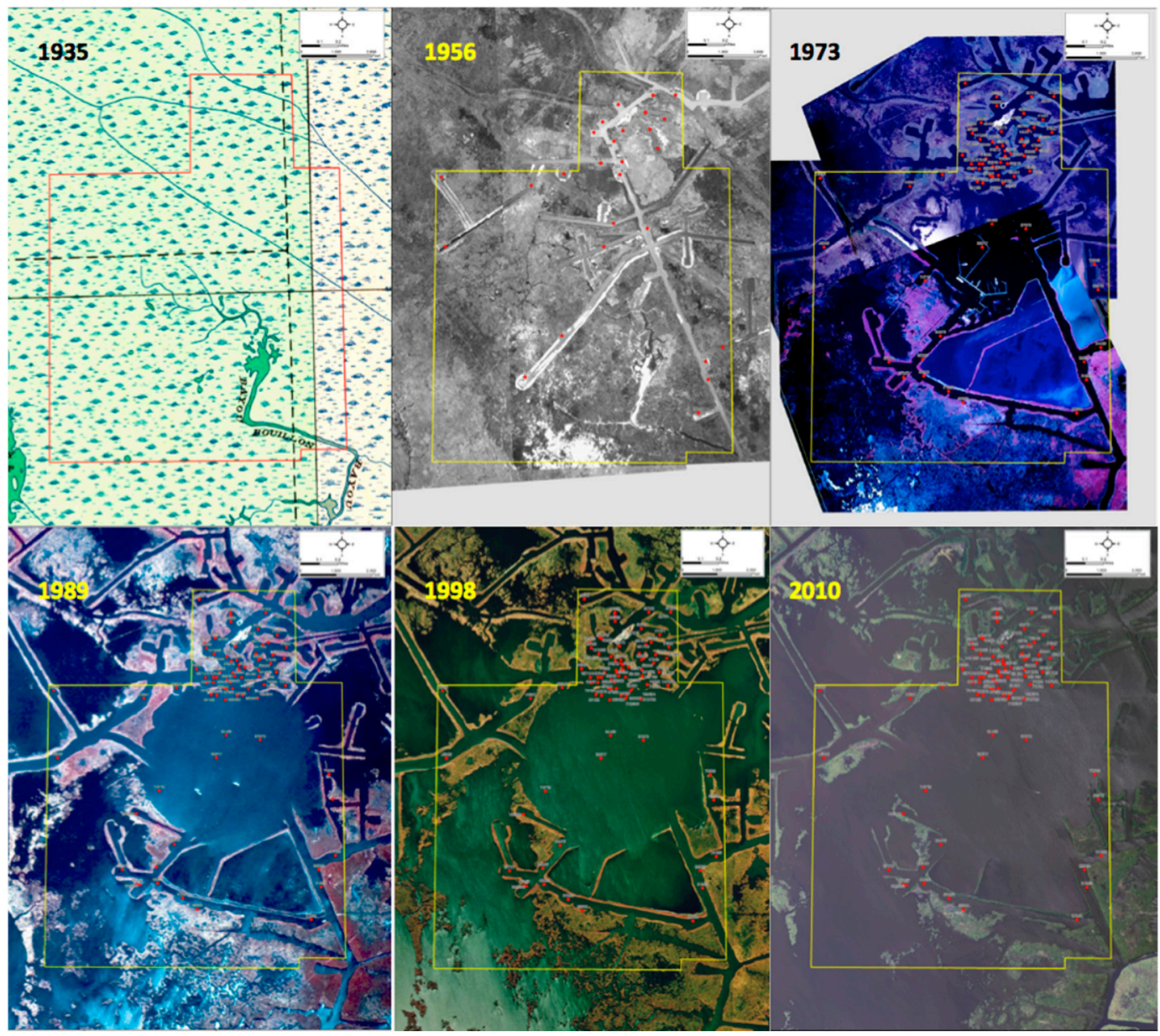

Figure 18. Images of the Bully Camp oil and gas field over time. The yellow line denotes an ownership tract in the field and red dots show locations of oil and gas wells. Note that land loss has been pervasive over the general area of the field. The central water body in the 1989 image is over an area of sulfur production on the top of the salt dome underlying this field. The narrow blue lines in the 1935 map are abandoned minor distributary ridges that were breached by canals (images from [76]).

\section{Restoration}

A well-designed restoration plan should be based on information about the impacts during the life cycle of $O \& G$ fields. Restoration of wetlands lost due to $O \& G$ activities will involve a synergistic approach that deals with the damage of O\&G impacts and rebuilds a functioning coastal wetland system. A central objective in restoration is rebuilding elevation due to both surface subsidence caused by altered hydrology and subsurface induced subsidence. Subsurface induced subsidence cannot be reversed, so sediment must be added at the surface to offset both subsurface and surface subsidence. Options for restoration include (1) marsh creation and restoration using dredged sediments [114-117]; (2) full use of all available sediment resources including Mississippi River, GIWW, and sediments resuspended during storms [118,119]; and (3) hydrologic restoration such as backfilling canals and spoil bank management, and restoration of hydrologic networks [119-123]. Rebuilding natural levee ridges that have been severed by canals can help restore natural hydrology to prevent saltwater intrusion and reduce increased hydrologic energy caused by more direct connections between interior parts of the delta and the Gulf of Mexico.

Elevation can be built up by adding dredged material to shallow water bodies, some that were previously wetlands, to an elevation that will support marsh vegetation $[115,124,125]$. Restoration of open water and degraded wetland areas to sustainable marsh are of tremendous importance in coastal 
Louisiana. The 2017 Coastal Master Plan (CMP) for restoration of the Mississippi delta dedicates nearly $\$ 18$ billion to marsh creation (the largest investment in a single type of restoration project) and many of those projects include both a short-term and a long-term phase [126]. The short-term phase focuses on immediate actions needed to protect vulnerable marshes from the proximal causes of loss (saltwater intrusion, erosion, and other consequences of significant hydrologic modifications) using a combination of restoration techniques (especially hydrologic restoration and marsh creation using dredged sediments). Successful implementation of short-term strategies reduces rates of wetlands loss and provides the foundation for longer-term strategies. The long-term phase focuses on wetlands gains through Mississippi River sediment diversions and capture of sediments advected over the marsh surface, with the intent of encouraging development of a sustainable wetland ecosystem (https://www.lacoast.gov/new/about/Basin_data/te/Default.aspx).

Introduction of sediments, through placement of fill material and/or spray dredging, is a necessary component of marsh restoration in degraded O\&G fields and sediment can be pumped long distances, as is the case for many 2017 CMP projects [127-132]. Containment dikes are utilized to confine unconsolidated material until it settles and dewaters [120]. Then these dikes can be degraded or gapped to the same elevation as the marsh platform in order to allow water exchange and marsh drainage, to improve productivity and aeration, and increase capture of suspended sediments that are advected over the marsh surface.

Sediment addition increases marsh surface elevation, thus reducing flood stress to the plant community. The authors of [114] showed that raising the surface of a deteriorating Spartina alterniflora salt marsh by $10 \mathrm{~cm}$ using dredge spoil resulted in a twofold increase in aboveground biomass production after the second growing season. In [115] it was found that increased elevation through the deposition of a $2 \mathrm{~cm}$ layer of dredged material in a deteriorated Louisiana marsh increased percent cover of S. alterniflora three-fold within one year. The authors of [125] studied dead marshes near Leeville that were restored using dredged material and found that sediment-slurry addition increased the elevation of the marsh surface and alleviated stress associated with excessive inundation and high salinity. Primary production was highest at elevations ranging from 29 to $36 \mathrm{~cm}$ NAVD 88 (12-20 cm above ambient marsh), and decreased at elevations above $36 \mathrm{~cm}$ NAVD 88, where primary production was limited by insufficient flooding and low nutrient availability. Sediment subsidy increases soil mineral matter, soil fertility, and marsh elevation, and thereby reduces nutrient deficiency, flooding, and interstitial sulfide stresses, generating a more favorable environment for plant growth and potentially, marsh sustainability $[116,117]$.

After containment dikes are gapped, restored marsh will have connectivity with surrounding ecosystem and plants will naturally recruit to the area or they can be planted. Although the created marsh will be initially higher than surrounding marshes, it will settle and have a higher bulk density. It is likely that these created marshes will have a higher productivity and production of organic matter than surrounding marshes. The plant species richness should the same as surrounding marshes, which is not very high in brackish and salt marshes of coastal Louisiana compared to fresh marshes. Plant diversity and soil organic matter content are higher in brackish marsh than in salt marsh. Brackish marsh is typically dominated by Spartina patens (marshhay cordgrass). Other significant associated species include Distichlis spicata (salt grass), Schoenoplectus olneyi (three-cornered grass), S. robustus (salt marsh bulrush), Eleocharis parvula (dwarf spikesedge), Ruppia maritima (widgeon grass), Paspalum vaginatum (seashore paspalum), Juncus roemerianus (black rush), Bacopa monnieri (coastal water hyssop), S. alterniflora (smooth cordgrass), and S. cynosuroides (big cordgrass) [130]. Salt marsh has the least plant diversity of any marsh type. The community is often totally dominated by smooth cordgrass. Significant associate species includes marshhay cordgrass, salt grass, black rush, and Batis maritima (salt wort).

A tidal network needs to develop in the restored marsh. All restoration plans need a component that focuses on natural hydrological functioning. A large-scale restoration project on Delaware Bay indicated that if a few primary channels were dredged, the system would naturally then develop a full 
tidal channel network $[130,131]$. The project involved restoration of tidal flooding by breeching dikes around formerly diked salt-hay farm and re-excavation of tidal creeks. Hydrologic design occurred in a "self-design" fashion after only initial cuts by construction of the largest (class 1) channels.

Spoil bank and canal management should be part of a restoration plan. Some canals should be backfilled as much as possible by pushing spoil banks back into canals. As spoil banks have settled and organic matter has decomposed, canals cannot be fully filled in using material from spoil banks. Thus, dredged material will have to be used to fully fill canals. In some cases, spoil banks should be left in place to protect remaining marshes from wave attack (see Figure 13).

After the marsh is restored and natural hydrology has been re-established, full use of all available sediments should be incorporated into the restoration design. Important sources of sediments include Mississippi/Atchafalaya Rivers as well as smaller rivers, sediment diversions, the Gulf Intracoastal Waterway, and sediments resuspended by storms [118]. Water sources with appreciable levels of nutrients should be used where possible to enhance marsh production including upland runoff, agricultural drainage, and treated municipal effluent $[133,134]$.

When planning restoration priorities, consideration should be given to the more stable underlying geologic framework choices, and avoidance of those areas still in the actively degrading part of the cycle. Examples include marsh construction on the more stable upthrown side of a fault, rather than the subsidence compaction and fault affected O\&G field on the downthrown side. The authors of [14] discussed the role of faulting in wetland loss in the Mississippi delta. In [135] the authors pointed to failed restoration projects where faulting has not been considered. Thus, taking into consideration underlying geology can lead to more successful and sustainable restoration.

Decontamination of restored sites is an integral part of restoration. In many cases, toxins can be buried in place but in some instances the contaminants have to be removed [4]. In addition to environmental impacts associated with land loss from $O \& G$ production operations, there often is environmental damage to soil and groundwater contamination that may have occurred from these same types of $O \& G$ operations. These damages include contamination to soils, groundwater, and in some cases underground sources of drinking water. These types of damages require extensive testing and the restoration includes soil treatment or removal and the cleanup of contaminated freshwater zones. Dealing with contamination can involve removal of the surface waste, excavation of 'hot spots' of concentrated pollution (chemicals of concern, COC) followed by treatment and disposal, and pumping and treatment of contaminated groundwater followed by treatment or subsurface injection. The goal of the remediation effort is to return the soil and groundwater to agreed-upon standards such as background soil standards contained in the La. DNR/OC regulations known as 29B (the section of the rules) and the La. DEQ RECAP (Risk Evaluation/Corrective Action Program) for both soil and groundwater. A mix of the standards is sometimes used. The term 'agreed upon' is used because cleanup is usually done in the context of a legal action with the involvement of the landowner-plaintiff, the oil companies(s), DNR, DEQ, and the Court. The DNR 29B (Title 43, Part XIX, statewide order 29B) standards were/are heavily influenced by the oil and gas exploration and production industry (E\&P) while the DEQ RECAP standards are based on risk science (LAC 33, 2003; https://www.deq.louisiana.gov/assets/docs/Land/RECAP/RECAPfinal.pdf). RECAP provides numerical screening standards for many chemicals in soil and groundwater and three management options. In many cases, addressing land loss and environmental cleanup must be done at the same time to fully restore the land.

In planning for restoration of degraded wetlands in O\&G fields, there should be coordination with other projects. For example, beneficial use of dredged sediments, where available, can be used to raise elevation. There are numerous wetland restoration projects taking place in the Mississippi Delta. These include marsh creation, river diversions, hydrologic restoration, barrier island restoration, rebuilding of distributary ridges, and shoreline protection $[126,136]$. Restoration of the impacts of O\&G activities involves to a lessor or greater degree all of these activities. For example, where sediment diversions are planned in the vicinity of an $O \& G$ field that is being restored, maximum use of diverted 
sediments should be a goal of the project. As noted above, beneficial use of sediments dredged for other activities such as navigation canal maintenance should be considered for marsh creation in restoring wetlands degraded by O\&G activities. Hydrologic restoration and natural levee restoration in the vicinity of a restoration project in an O\&G field should be done in a way that compliments the larger efforts. In this way, the restoration of and O\&G field can be done to increase benefits over a larger area.

\section{Summary and Conclusions}

Oil and gas activity has been pervasive in the Mississippi delta and both production and environmental impacts follow a predictable life cycle. There are hundreds of O\&G fields in coastal Louisiana, as well as a dense network of canals associated with drilling access, navigation, and pipelines. The production history for individual fields can last 40-60 years with production rising rapidly to a peak around 1970 and then declining. Since most drilling started in the 1940s and 1950s, most wells are no longer producing or are in the final stages of production and this cycle conclusion holds true for aggregate MRD production. Most fields had very low levels of production by the 2000s. Produced water generally lagged $O \& G$ production and was generally higher during declining O\&G production.

Oil and gas activities have contributed in three major ways to environmental impacts on coastal ecosystems and specifically to wetland loss. These include alteration of surface hydrology due to canal dredging and spoil placement, induced subsidence and fault re-activation due to fluids withdrawal, and toxic stress due to pollution by spilled oil and produced water. Wetland loss due to O\&G gas activity is initially due mainly to direct impacts of canal dredging and spoil placement, but grows over time due to cumulative and interactive effects. This wetland loss then grows over time to encompass much of the field and adjacent areas. Networks of interconnected canals form new patterns of water flow and often lead to saltwater intrusion. Interestingly, spoil banks are not necessarily a permanent landscape feature and have a life cycle of their own. They subside and compact over time and a quarter to a third of spoil banks likely have no subaerial expression.

Fluid withdrawal from O\&G formations leads to induced subsidence and fault activation [91]. Induced subsidence occurs in two phases. Withdrawal of O\&G and produced water induce reservoir compaction resulting in a reduction of reservoir thickness. A slow drainage of pore pressure in the bounding shale mainly due to water pumping induces time-delayed shale compaction and subsidence can continue for decades after most O\&G has been produced. This results in subsidence over much of the oil fields that can be greater than surface subsidence due to altered hydrology.

Produced water from O\&G fields is water brought to the surface during O\&G extraction and generally includes a mixture of either liquid or gaseous hydrocarbons, high salinity produced water, dissolved or suspended solids, produced solids such as sand or silt, and injected fluids and additives associated with exploration and production activities. Produced water has been shown to be toxic to many estuarine organisms including vegetation and consumers. Spilled oil has been shown to have lethal and sub-lethal effects of a wide range of estuarine organisms. The three main types of impact of O\&G activities act in cumulative, synergistic, and indirect ways that lead to greater overall impact. Restoration of wetlands lost due to O\&G activities will involve a synergistic approach that deals with the damage of O\&G impacts and rebuilds a functioning coastal wetland system.

Restoration should be the final stage in the life cycle of O\&G fields. A central objective of restoration is restoring lost elevation. Options for restoration include marsh creation and restoration using dredged sediments, full use of all available sediment resources, and hydrologic restoration. Decontamination of restored sites is an integral part of restoration.

Author Contributions: All authors contributed to the writing of this review manuscript. All authors have read and agreed to the published version of the manuscript.

Funding: This research did not receive any specific grant from funding agencies in the public, commercial, or not-for-profit sectors. 
Conflicts of Interest: J.W.D., H.C.C., R.G.H., and C.R.N. state that they are engaged as experts in lawsuits regarding the environmental impacts of oil and gas activity on coastal ecosystems. No funding from these activities was used for the preparation of this paper.

\section{References}

1. Theriot, J.P. Oilfield battleground: Louisiana's legacy lawsuits in historical perspective. La. Hist. J. La. Hist. Assoc. 2016, 57, 403-462.

2. Bass, A.S.; Turner, R.E. Relationships between salt marsh loss and dredged canals in three Louisiana estuaries. J. Coast. Res. 1997, 13, 895-903.

3. Cahoon, D.; Turner, R.E. Accretion and canal impacts in a rapidly subsiding wetland II. Feldspar marker horizon technique. Estuaries 1989, 12, 260-268. [CrossRef]

4. Ko, J.Y.; Day, J.W. A review of ecological impacts of oil and gas development on coastal ecosystems in the Mississippi Delta. Ocean Coast. Manag. 2004, 47, 597-623. [CrossRef]

5. Day, J.; Shaffer, G.; Cahoon, D.; DeLaune, R. Canals, backfilling and wetland loss in the Mississippi Delta. Estuar. Coast. Shelf Sci. 2019. [CrossRef]

6. Gould, H.R.; McFarlan, E., Jr. Geologic history of the Chenier Plain, southwestern Louisiana. Trans. Gulf Coast Assoc. Geol. Soc. 1959, 9, 261-270.

7. Penland, S.; Sutor, J.R. The geomorphology of the Mississippi River chenier plain. Mar. Geol. 1989, 90, 231-240. [CrossRef]

8. Roberts, H.H. Dynamic changes of the holocene Mississippi river delta plain: The delta cycle. J. Coast. Res. 1997, 13, 605-627.

9. Day, J.W., Jr.; Britsch, L.D.; Hawes, S.R.; Shaffer, G.P.; Reed, D.J.; Cahoon, D. Pattern and process of land loss in the Mississippi Delta: A spatial and temporal analysis of wetland habitat change. Estuaries 2000, 23, 425-438. [CrossRef]

10. Blum, M.D.; Roberts, H.H. The Mississippi delta region: Past, present, and future. Annu. Rev. Earth Planet. Sci. 2012, 40, 655-683. [CrossRef]

11. Williams, S.J.; Penland, S.; Roberts, H.H. Processes affecting coastal wetland loss in the Louisiana deltaic plain. In Processes of Coastal Wetlands Loss in Louisiana; Presented at Coastal Zone '93; USGS Open-File Report 94-0275; Williams, S.J., Cichon, H.A., Eds.; USGS: New Orleans, LA, USA, 1994; pp. 21-29.

12. Kulp, M.A. Holocene Stratigraphy, History, and Subsidence: Mississippi River Delta Region, North-Central Gulf of Mexico. Ph.D. Thesis, University of Kentucky, Lexington, KY, USA, 2000; p. 336.

13. Reed, D.J. Sea-level rise and coastal marsh sustainability: Geological and ecological factors in the Mississippi delta plain. Geomorphology 2002, 48, 233-243. [CrossRef]

14. Gagliano, S.M.; Kemp, E.B.; Wicker, K.M.; Wiltenmuth, K.S. Active Geological Faults and Land Change in Southeastern Louisiana, Final Report; Contract No. DACW 29-00-C-0034; Coastal Environments, Inc., United States Army Corps of Engineers: New Orleans, LA, USA, 2003; p. 177.

15. Reed, D.J.; Wilson, L. Coast 2050: A new approach to restoration of Louisiana coastal wetlands. Phys. Geogr. 2004, 25, 4-21. [CrossRef]

16. Turner, R.E.; Cahoon, D.R. (Eds.) Causes of Wetland Loss in the Coastal Central Gulf of Mexico, Volume II: Technical Narrative; Contract No. 14-12-0001-30252. OCS Study/MMS 87-0120; Prepared for Minerals Management Service: New Orleans, LA, USA, 1987; p. 400.

17. USACE (U.S. Dept of the Army Corps of Engineers). Louisiana Coastal Area (LCA), Louisiana Ecosystem Restoration Study, Final Volume 1-LCA Study, Main Report. 2004. Available online: http://www.lca.gov/ final_report.aspx (accessed on 20 January 2020).

18. Turner, R.E.; McClenachan, G. Reversing wetland death from 35,000 cuts: Opportunities to restore Louisiana's dredged canals. PLoS ONE 2018, 13, e0207717. [CrossRef] [PubMed]

19. Olea, R.A.; Coleman, J.L., Jr. A synoptic examination of causes of land loss in Southern Louisiana as related to the exploitation of subsurface geologic rsources. J. Coast. Res. 2014, 30, 1025-1044. [CrossRef]

20. Morton, R.A.; Bernier, J.C.; Barras, J.A. Evidence of regional subsidence and associated interior wetland loss induced by hydrocarbon production, Gulf Coast region, USA. Environ. Geol. 2006, 50, 261-274. [CrossRef] 
21. Pe, K.M. An Assessment of Produced Water Impacts to Low-Energy Brackish Water Systems in Southeast Louisiana; Louisiana Department of Environmentally Quality, Water Pollution Control Division: Baton Rouge, LA, USA, 1990; p. 204.

22. Rabalais, N.N.; McKee, B.A.; Reed, D.J.; Means, J.C. Fate and effects of produced water discharges in coastal Louisiana, Gulf of Mexico, USA. In Produced Water; Springer: Boston, MA, USA, 1992; pp. 355-369.

23. Neto, A.G.; Costa, C.S.B. Survival and growth of the dominant salt marsh grass Spartina alterniflora in an oil industry saline wastewater. Int. J. Phytoremediation 2009, 11, 640-650. [CrossRef]

24. Penland, S.; Wayne, L.; Britsch, L.D.; Williams, S.J.; Beall, A.D.; Butterworth, V.C. Geomorphic classification of coastal land loss between 1932 and 1990 in the Mississippi River delta plain, southeastern Louisiana; U.S. Geological Survey Open-File Report 00-417, 1 sheet; USGS: New Orleans, LA, USA, 2000.

25. Penland, S.; Wayne, L.; Britsch, L.D.; Williams, S.J.; Beall, A.D.; Butterworth, V.C. Process classification of coastal land loss between 1932 and 1990 in the Mississippi River delta plain, southeastern Louisiana; U.S. Geological Survey Open-File Report 00-418, 1 sheet; USGS: New Orleans, LA, USA, 2000.

26. Turner, R.E. Relationship between Canal and Levee Density and Coastal Land Loss in Louisiana; US Fish Wildlife Service Biological Report 85(14); Department of Interior: Washington, DC, USA, 1987; p. 58.

27. Turner, R.E. Wetland loss in the Northern Gulf of Mexico: Multiple working hypotheses. Coast. Estuar. Res. Fed. 1997, 20,1-13. [CrossRef]

28. Chan, A.W.; Zoback, M.D. The role of hydrocarbon production on land subsidence and fault reactivation in the Louisiana coastal zone. J. Coast. Res. 2007, 23, 771-786. [CrossRef]

29. Chang, C.; Mallman, E.; Zoback, M. Time-dependent subsidence associated with drainage-induced compaction in Gulf of Mexico shales bounding a severely depleted gas reservoir. AAPG Bull. 2014, 98, 1145-1159. [CrossRef]

30. Morton, R.A.; Bernier, J.C.; Barras, J.A.; Ferina, N.F. Rapid subsidence and historical wetland loss in the south-central Mississippi delta plain: Likely causes and future implications. U.S. Geological Survey Open-file Report 2005-1216; 2005. Available online: http://www.pubs.usgs.gov/of/2005/1216 (accessed on 6 June 2019).

31. IHS Energy Group. PI/Dwights Plus U.S. Production Data on CD: Available from IHS Energy Group, 15 Inverness Way East, D205; IHS Energy Group: Englewood, CO, USA, 2003.

32. Britsch, L.D.; Dunbar, J.B. Land loss rates: Louisiana coastal plain. J. Coast. Res. 1993, 9, 324-338.

33. Couvillion, B.; Barras, J.; Steyer, G.; Sleavin, W.; Fishcher, M.; H, B.; Trahan, N.; Griffin, B.; Heckman, D. Land area change in coastal Louisiana from 1932 to 2010; Scientific Investigations Map 3164, scale 1, 265,000; U.S. Geological Survey: New Orleans, LA, USA, 2011; 12p. Available online: https://pubs.usgs.gov/sim/3381/ sim3381.pdf (accessed on 23 July 2016).

34. Couvillion, B.R.; Beck, H.; Schoolmaster, D.; Fischer, M. Land Area Change in Coastal Louisiana 1932 to 2016; Scientific Investigations Map 3381; U.S. Geological Survey: New Orleans, LA, USA, 2017; 16p.

35. Gagliano, S.M.; van Beek, J.L. Geologic and geomorphic aspects of deltaic processes, Mississippi delta system. In Hydrologic and Geologic Studies of Coastal Louisiana; Gagliano, S.M., Muller, R., Light, P., Al-Awady, M., Eds.; La State Univ, Coastal Studies Institute and Dept of Marine Sciences: Baton Rouge, LA, USA, 1970; Volume I, p. 140.

36. Gagliano, S.M. Canals, dredging and land reclamation in the Louisiana coastal zone. In Hydrologic and Geologic Studies of Coastal Louisiana; Report no. 14; Center for Wetland Resources, Louisiana State University: Baton Rouge, LA, USA, 1973; p. 104.

37. Craig, N.J.; Turner, R.E.; Day, J.W., Jr. Land loss in coastal Louisiana (U.S.A.). Environ. Manag. 1979, 3, 133-144. [CrossRef]

38. Turner, R.E.; Costanza, R.; Scaife, W. Canals and land loss in coastal Louisiana. In Proceedings of the Conference on Coastal Erosion and Wetland Modification in Louisiana: Causes, consequences, and options, Baton Rouge, LA, USA, 5-7 October 1981, pp. 73-84; Boesch, D.F., Ed.; National Coastal Ecosystems Team, Office of Biological Services, Fish and Wildlife Service, US Department of the Interior, Washington, DC, USA, 1982; p. 256.

39. Scaife, W.W.; Turner, R.E.; Costanza, R. Coastal Louisiana recent land loss and canal impacts. Environ. Manag. 1983, 7, 433-442. [CrossRef]

40. Deegan, L.A.; Kennedy, H.M.; Neill, C. Natural factors and human modifications contributing to marsh loss in Louisiana's Mississippi River deltaic plain. Environ. Manag. 1984, 8, 519-528. [CrossRef]

41. Turner, R.E. Landscape development and coastal wetland losses in the Northern Gulf of Mexico. Am. Zool. 1990, 30, 89-105. [CrossRef] 
42. Baumann, R.H.; Turner, R.E. Direct impacts of outer continental shelf activities on wetland loss in the central Gulf of Mexico. Environ. Geol. Wat. Sci. 1990, 15, 189-198. [CrossRef]

43. Boesch, D.F.; Josselyn, M.N.; Mehta, A.J.; Morris, J.T.; Nuttle, W.K.; Simenstad, C.A.; Swift, D.J.P. Scientific assessment of coastal wetland loss, restoration and management. J. Coast. Res. Special Issue No. 1994, 20, $1-103$.

44. Barras, J.A. 2006, Land area change in coastal Louisiana after the 2005 hurricanes-A series of three maps: U.S. Geological Survey Open-File Report 2006-1274. Available online: http://pubs.usgs.gov/of/2006/1274/ (accessed on 19 October 2018).

45. Doiron, L.N.; Whitehurst, C.A. Geomorphic Processes Active in the Southeast Louisiana Canal; Research Monographs, Division of Engineering Research-RM 5: LaFourche Parish, LA, USA, 1974; p. 48.

46. Davis, D.W. Louisiana canals and their influence on wetland development. Ph.D. Thesis, Louisiana State University, Baton Rouge, LA, USA, 1973; p. 234.

47. Gagliano, S.M.; Wicker, K.M. Processes of wetland erosion in the Mississippi River Deltaic Plain, p. $28-48$. In Marsh Management in Coastal Louisiana: Effects and Issues_Proceedings of a Symposium; United States Fish and Wildlife Service Biological Report; Duffy, W.G., Clark, D., Eds.; United States Fish and Wildlife Service and Louisiana Department of Natural Resources: Washington, DC, USA, 1989.

48. Reed, D.J. Status and Historical Trends of Hydrologic Modification, Reduction in Sediment Availability, and Habitat Loss/Modification in the Barataria and Terrebonne Estuarine System; BTNEP Publ. No. 20; Barataria-Terrebonne National Estuary Program: Thibodaux, LA, USA, 1995; p. 338.

49. Day, J.; Rybczyk, J.; Scarton, F.; Rismondo, A.; Are, D.; Cecconi, G. Soil accretionary dynamics, sea-level rise and the survival of wetlands in Venice Lagoon: A field and modeling approach. Estuar. Coast. Shelf Sci. 1999, 49, 607-628. [CrossRef]

50. Johnston, J.B.; Cahoon, D.R.; la Peyre, M.K. Outer Continental Shelf(OCS)-Relatedpipelines and Navigation Canals in the Western and Central Gulf of Mexico: Relative Impacts on Wetland Habitats and Effectiveness of Mitigation; OCS Study MMS 2009-048; U.S. Dept. of the Interior, Minerals Management Service, Gulf of Mexico OCS Region: New Orleans, LA, USA, 2009; p. 200.

51. Swenson, E.M. Marsh Hydrological Studies, 1982-1983 Data Report; Prepared for the National Marine Fisheries Service, Southeast Region, St. Petersburg, Florida. Contract no. NA81-BA-P00006. Publication no. LSU-CEFI-83-18; Coastal Ecology Institute, Center for Wetland Resources, Louisiana State University: Baton Rouge, LA, USA, 1983.

52. Swenson, E.M.; Turner, R.E. Spoil banks: Effects on a coastal marsh water-level regime. Estuar. Coast. Shelf Sci. 1987, 24, 599-609. [CrossRef]

53. Mendelssohn, I.A.; McKee, K.L. Spartina alterniflora die-back in Louisiana: Time-course investigation of soil waterlogging effects. J. Ecol. 1988, 76, 509-521. [CrossRef]

54. Day, R.; Holz, R.; Day, J. An inventory of wetland impoundments in the coastal zone of Louisiana, USA: Historical trends. Environ. Manag. 1990, 14, 229-240. [CrossRef]

55. Taylor, N.C.; Day, J.W.; Neusaenger, G.E. Ecological characterization of Jean Lafitte National Historical Park, Louisiana: Basis for a management plan. In Marsh Management in Coastal Louisiana: Effects and Issues_Proceedings of a Symposium; Baton Rouge, LA, USA, 7-10 June 1988; Duffy, W.G., Clark, D., Eds.; United States Fish and Wildlife Service and Louisiana Department of Natural Resources: Washington, DC, USA, 1989.

56. Cahoon, D.R.; Groat, C.G. A Study of Marsh Management Practice in Coastal Louisiana; Executive Summary; U.S. Dept. of the Interior, Minerals Management Service, Gulf of Mexico OCS Region: New Orleans, LA, USA, 1990; Volume 1, p. 36.

57. Reed, D.J. Effect of weirs on sediment deposition in Louisiana coastal marshes. Environ. Manag. 1992, 16, 55-65. [CrossRef]

58. Reed, D.J.; Cahoon, D.R. The relationship between marsh surface topography and vegetation parameters in a deteriorating Louisiana Spartina alterniflora salt marsh. J. Coast. Res. 1992, 8, 77-87.

59. Rogers, D.R.; Rogers, B.D.; Herke, W.H. Effects of a marsh management plan on fishery communities in coastal Louisiana. Wetlands 1992, 12, 53-62. [CrossRef]

60. Boumans, R.M.; Day, J.W. Effects of two Louisiana marsh management plans on water and materials flux and short-term sedimentation. Wetlands 1994, 14, 247-261. [CrossRef] 
61. Cahoon, D.R. Recent accretion in two managed marsh impoundments in coastal Louisiana. Ecol. Appl. 1994, 4, 166-176. [CrossRef]

62. Asano, T. Sediment transport under sheet-flow conditions. J. Waterw. Port Coast. Ocean Eng. ASCE 1995, 121, 239-246. [CrossRef]

63. Gascuel-Odux, C.; Cros-Cayot, S.; Durand, P. Spatial variations of sheet flow and sediment transport on an agricultural field. Earth Surf. Process. Landf. 1996, 21, 843-851. [CrossRef]

64. Neill, C.; Turner, R.E. Backfilling canals to mitigate wetland dredging in Louisiana coastal marshes. Environ. Manag. 1987, 11, 823-836. [CrossRef]

65. Taylor, N.C. Ecological characterization of Jean Lafitte National Historical Park. Louisiana: Basis for a management plan. Master's Thesis, Louisiana State University, Baton Rouge, LA, USA, 1988.

66. Reed, D.J.; de Luca, N.; Foote, A.L. Effect of hydrologic management on marsh surface sediment deposition in coastal Louisiana. Estuaries 1997, 20, 301-311. [CrossRef]

67. Jarvis, J.C. Vertical Accretion Rates in Coastal Louisiana: A Review of the Scientific Literature; ERDC/EL TN-10-5; U.S. Army Engineer Research and Development Center: Vicksburg, MS, USA, 2010; p. 15.

68. Sasser, C.E.; Dozier, M.D.; Gosselink, J.G.; Hill, J.M. Spatial and temporal changes in Louisiana's Barataria basin marshes, 1945-1980. Environ. Manag. 1986, 10, 671-680. [CrossRef]

69. Wang, F.C. Dynamics of saltwater intrusion in coastal channels. J. Geophys. Res. 1988, 93, 6937-6946. [CrossRef]

70. Turner, R.E.; Rao, Y.S. Relationships between wetland fragmentation and recent hydrologic changes in a deltaic coast. Estuaries 1990, 13, 72-281. [CrossRef]

71. Shaffer, G.; Day, J.; Mack, S.; Kemp, P.; van Heerden, I.; Poirrier, M.; Westphal, K.; FitzGerald, D.; Milanes, A.; Morris, C.; et al. The MRGO navigation project: A massive human-induced environmental, economic, and storm disaster. J. Coast. Res. 2009, 54, 206-224. [CrossRef]

72. McKee, K.L.; Mendelssohn, I.A. Response of a freshwater marsh plant community to increased salinity and increased water level. Aquat. Bot. 1989, 34, 301-316. [CrossRef]

73. Mendelssohn, I.A.; Morris, J.T. Eco-physiological controls on the productivity of Spartina alterniflora loisel. In Concepts and Controversies in Tidal Marsh Ecology; Weinstein, M.P., Kreeger, D.A., Eds.; Kuwer Academic Publishers: Boston, MA, USA, 2000; pp. 59-80.

74. Day, J.W.; Kemp, G.P.; Reed, D.J.; Cahoon, D.R.; Boumans, R.M.; Suhayda, J.M.; Gambrell, R. Vegetation death and rapid loss of surface elevation in two contrasting Mississippi delta salt marshes: The role of sedimentation, autocompaction and sea-level rise. Ecol. Eng. 2011, 37, 229-240. [CrossRef]

75. Nyman, J.A.; DeLaune, R.D.; Patrick, W.H., Jr. Wetland soil formation in the rapidly subsiding Mississippi River Deltaic Plain: Mineral and organic matter relationships. Estuar. Coast. Shelf Sci. 1990, 31, 57-69. [CrossRef]

76. Gagliano, S. Assessment of Environmental Impacts Associated with Oil and Gas Exploration and Development in the Bully Camp Oil and Gas Field Lafourche Parish, Louisiana; Jones, Swanson, Huddell \& Garrison: New Orleans, LA, USA, 2017.

77. Nichols, L.G. Technical Report of the Louisiana Wildlife and Fisheries Commission, Rockefeller Refuge levee study; Louisiana Wildlife and Fisheries Commission, Refuge Division: New Orleans, LA, USA, 1959.

78. Bondesan, M.; Castiglioni, G.; Elmi, C.; Gabbianelli, G.; Marocco, R.; Pirazzoli, P.; Tomasin, A. Coastal areas at risk from storm surges and sea-level rise in northeastern Italy. J. Coast. Res. 1995, 11, 1354-1379.

79. Mallman, E.P.; Zoback, M.D. Subsidence in the Louisiana Coastal Zone due to hydrocarbon production. J. Coast. Res. 2007, 50, 443-449.

80. Dokka, R.K. The role of deep processes in late 20th century subsidence of New Orleans and coastal areas of southern Louisiana and Mississippi. J. Geophys. Res. 2011, 116, B06403. [CrossRef]

81. Caro Guenca, M.; Hanssen, R.; Hooper, A.; Arikan, M. Surface deformation of the whole Netherlands after PSI analysis. In Proceedings of the Fringe 2011 Workshop, Frascati, Italy, 19-23 September 2011. ESA SP-697.

82. Kolker, A.S.; Allison, M.A.; Hameed, S. An evaluation of subsidence rates and sea level variability in the northern Gulf of Mexico. Geophys. Res. Lett. 2011, 38, L21404. [CrossRef]

83. Yu, S.-Y.; Tornqvist, T.E.; Hu, P. Quantifying Holocene lithospheric subsidence rates underneath the Mississippi Delta. Earth Planet. Sci. Lett. 2012, 331, 21-30. [CrossRef]

84. Morton, R.A.; Buster, N.A.; Krohn, M.D. Subsurface controls on historical subsidence rates and associated wetland loss in southcentral Louisiana. Trans. Gulf Coast Assoc. Geol. Soc. 2002, 52, 767-778. 
85. Gagliano, S.M.; Haggar, K.S. Effects of D-shaped fault deformation on south Louisiana landscape (abs.); Annual Convention 2010 Programs and Abstracts; American Association of Petroleum Geologists: New Orleans, LA, USA, 2010.

86. Morton, R.A.; Bernier, J.C. Recent subsidence-rate reductions in the Mississippi delta and their geological implications. J. Coast. Res. 2010, 29, 555-561. [CrossRef]

87. Armstrong, C.; Mohrig, D.; Hess, T.; George, T.; Straub, K. Influence of growth faults on coastal fluvial systems: Examples from the late Miocene to Recent Mississippi River Delta. Sediment. Geol. 2014, 301, 120-132. [CrossRef]

88. Levesh, J.L.; McLindon, C.; Kulp, M.A. A Detailed Study of the Delacroix Island Major Fault and Its Role on Stratigraphic Horizons from the Middle Miocene to Present, Abstract. In Proceedings of the AGU Fall Meeting, New Orleans, LA, USA, 11-15 December 2017.

89. Culpepper, M.; McDade, E.C.; Dawers, N.; Zhang, R. Synthesis of Fault Traces in SE Louisiana Relative to Infrastructure: Project No. 17GTLSU12; Transportation Consortium of South Central States: San Antonio, TX, USA, 2019; p. 53.

90. Straub, K.; Mohrig, D. Subsidence Associated with Active Growth Faulting on the Mississippi Delta: Displacement Rates and Steering of the Mississippi River; Presented at Long Term Estuary Assessment Group: New Orleans, LA, USA, 2010; Available online: http://leag.tulane.edu/PDFs/Straub-LEAG-4.28.10.pdf (accessed on 12 February 2019).

91. Hillis, R. Pore pressure/stress coupling and its implications for seismicity. Explor. Geophys. 2000, 31, 448-454. [CrossRef]

92. Zoback, M.D.; Zinke, J.C. Production-induced normal faulting in the Valhall and Ekofisk oil fields. In The Mechanism of Induced Seismicity; Trifu, C.I., Ed.; Pageoph Topical Volumes, Birkhauser: Basel, Switzerland, 2002; pp. 403-420.

93. Pratt, W.E.; Johnson, D.W. Local subsidence of the Goose Creek oil field. J. Geol. 1926, 34, 577-590. [CrossRef]

94. Geertsma, J. Land subsidence above compacting oil and gas reservoirs. J. Pet. Technol. 1973, 25, 734-744. [CrossRef]

95. Chang, C.; Zoback, M.D. Viscous creep in room-dried unconsolidated Gulf of Mexico shale (I): Experimental results. J. Pet. Sci. Eng. 2009, 69, 239-246. [CrossRef]

96. Baú, D.; Gambolati, G.; Teatini, P. Residual land subsidence over depleted gas fields in the Northern Adriatic Basin. Environ. Eng. Geosci. 1999, 5, 389-405. [CrossRef]

97. Hettema, M.; Papamichos, E.; Schutjens, P.M.T.M. Subsidence delay: Field observations and analysis. Oil Gas Sci. Technol. 2002, 57, 443-458. [CrossRef]

98. Dusseault, M.B.; Bruno, M.S.; Barrera, J. Casing shear: Causes, cases, cures. SPE Drill. Completion 2001, 16, 98-107. [CrossRef]

99. Boesch, D.F.; Rabalais, N.N. (Eds.) Produced Waters in Sensitive Coastal Habitats: An Analysis of Impacts, Central Coastal Gulf of Mexico; OCS Report/MMS 89-0031; U.S. Dept. of the Interior, Minerals Management Service, Gulf of Mexico OCS Regional Office: New Orleans, LA, USA, 1989; p. 157.

100. Veil, J.A.; Puder, G.M.; Elcock, D.; Redweik, R.J. A White Paper Describing Produced Water from Production of Crude Oil, Natural Gas, and Coal Bed Methane; No. ANL/EA/RP-112631; Argonne National Lab: Lemont, IL, USA, 2004.

101. American Petroleum Institute (API). Produced water impacts on Louisiana wetlands. Health and Environmental Sciences API Publication Number 4517; API: Washington, DC, USA, 2000.

102. Veil, J.A.; Kimmell, T.A.; Rechner, A.C. Characteristics of Produced Water Discharged to the Gulf of Mexico Hypoxic Zone; Report to the U.S. Dept. of Energy; National Energy Technology Laboratory, Argonne National Laboratory: Washington, DC, USA, 2005.

103. Neff, J.; Lee, K.; DeBlois, E.M. Produced water: Overview of composition, fates, and effects. In Produced Water; Springer: New York, NY, USA, 2011; pp. 3-54.

104. Rabalais, N.N.; McKee, B.A.; Reed, D.J.; Means, J.C. Fate and Effects of Nearshore Discharges of OCS Produced Waters; Executive Summary; OCS Study/MMS 91-0004; U.S. Dept. of the Interior, Minerals Management Service, Gulf of Mexico OCS Regional Office: New Orleans, LA, USA, 1991; Volume 1, p. 48.

105. Haque, S.M. Effects of surface brine disposal on the marshes of coastal Louisiana. In Proceedings of the Coastal Zone, New Orleans, LA, USA, 19-23 July 1993. 
106. Bass, A.S. Accidental Oilfield Brine Spill Impact Study: A Survey of the Magnitude and Distribution of Accidental Brine Spills in the Louisiana Coastal Wetlands Conservation Area; Final Report; Louisiana Geological Survey Report submitted to the Louisiana Coastal Management Division, Louisiana Department of Natural Resources: Baton Rouge, LA, USA, 1998; 55p.

107. Lehto, B.; Marcantel, R.; Paul, W.B. Calcasieu-Sabine Cooperative River Basin Study Report; Report prepared for the United States Department of Agricultural and Soil Conservation Service; US Dept of Agricultural and Soil Cons Service: Baton Rouge, LA, USA, 1999; p. 293.

108. Louisiana Coastal Wetlands Conservation and Restoration Task Force. Hydrologic Investigation of the Louisiana Chenier Plain; Louisiana Department of Natural Resources, Coastal Restoration Division: Baton Rouge, LA, USA, 2002; p. 135.

109. Hamilton, L.D.; Meinhold, A.F.; Nagy, J. Produced Water Radionuclide Hazard/risk Assessment-Phase 1; API Publication Number 4532; American Petroleum Institute: Washington, DC, USA, 1991; p. 176.

110. Totten, S.; Matthew, W.; Hanan, M.A.; Simpson, S. Natural remediation of marsh soil contaminated by oil-field brine containing elevated radium levels, southern Louisiana. Environ. Geosci. 2007, 14, 113-122. [CrossRef]

111. McGenity, T.J.; Folwell, B.D.; McKew, B.A.; Sanni, G.O. Marine crude-oil biodegradation: A central role for interspecies interactions. Aquat. Biosyst. 2012, 8, 10. [CrossRef] [PubMed]

112. USEPA (United States Environmental Protection Agency). Water Quality Benefits Analysis of Final Effluent Limitations Guidelines and Standards for the Coastal Subcategory of the Oil and Gas Extraction Point Source Category; EPA-821-R-96-024; EPA: Washington, DC, USA, 1996.

113. Twilley, R.; Bentley, S.; Chen, Q.; Edmonds, D.; Hagen, S.; Lam, N.; Willson, C.; Xu, K.; Braud, D.; Peele, R.; et al. Co-evolution of wetland landscapes, flooding, and human settlement in the Mississippi River Delta Plain. Sustain. Sci. 2016, 11, 711-731. [CrossRef]

114. DeLaune, R.D.; Pezeshki, S.R.; Pardue, J.H.; Whitcomb, J.H.; Patrick, W.H., Jr. Some influences of sediment addition to a deteriorating salt marsh in the Mississippi River deltaic plain: A pilot study. J. Coast. Res. 1990, $6,181-188$.

115. Ford, M.A.; Cahoon, D.R.; Lynch, J.C. Restoring marsh elevation in a rapidly subsiding salt marsh by thin-layer deposition of dredged material. Ecol. Eng. 1999, 12, 189-205. [CrossRef]

116. Mendelssohn, I.A.; Kuhn, N.L. Sediment subsidy: Effects on soil plant responses in a rapidly submerging coastal salt marsh. Ecol. Eng. 2003, 21, 115-128. [CrossRef]

117. La Peyre, M.K.; Gossman, B.; Piazza, B.P. Short- and long-term response of deteriorating brackish marshes and open-water ponds to sediment enhancement by thin-layer dredge disposal. Estuaries Coasts 2009, 32, 390-402. [CrossRef]

118. Perez, B.; Day, J.; Rouse, L.; Shaw, R.; Wang, M. Influence of Atchafalaya River discharge and winter frontal passage on suspended sediment concentration and flux in Fourleague Bay, Louisiana. Estuar. Coast. Shelf Sci. 2000, 50, 271-290. [CrossRef]

119. Day, J.W.; Boesch, D.F.; Clairain, E.J.; Kemp, G.P.; Laska, S.B.; Mitsch, W.J.; Orth, K.; Mashriqui, H.; Reed, D.J.; Shabman, L.; et al. Whigham. Restoration of the Mississippi delta: Lessons from hurricanes Katrina and Rita. Science 2007, 315, 1679-1684. [CrossRef]

120. Turner, R.E.; Streever, B. Approaches to Coastal Wetland Restoration: Northern Gulf of Mexico; Kugler Publications: Amsterdam, The Netherlands, 2002; p. 147.

121. DeLaune, R.; Jugsujindaa, A.; Peterson, G.; Patrick, W. Impact of Mississippi River freshwater reintroduction on enhancing marsh accretionary processes in a Louisiana estuary. Estuar. Coast. Shelf Sci. 2003, 58, 653-662. [CrossRef]

122. Baustian, J.; Turner, R.E. Restoration Success of Backfilling Canals in Coastal Louisiana Marshes. Restor. Ecol. 2006, 14, 636-644. [CrossRef]

123. Day, J.; Paul, K.; Angelina, F. Summary and Conclusions. pp. 185-192. In Perspectives on the restoration of the Mississippi Delta; Day, J., Kemp, P., Freeman, A., Muth, D., Eds.; Springer: New York, NY, USA, 2014.

124. Ray, G.L. Thin Layer Placement of Dredged Material on Coastal Wetlands: A Review of the Technical and Scientific Literature; ERDC/EL Technical Notes Collection (ERDC/EL TN-07-1); U.S. Army Engineer Research and Development Center: Vicksburg, MS, USA, 2007.

125. Stagg, C.L.; Mendelssohn, I.A. Restoring ecological function to a submerged salt marsh. Restor. Ecol. 2010, 18, 10-17. [CrossRef] 
126. CPRA-Coastal Protection and Restoration Authority. Louisiana's Comprehensive Master Plan for a Sustainable Coast; CPRA: Baton Rouge, LA, USA, 2017; p. 93.

127. Cahoon, D.R.; Cowan, J.H., Jr. Environmental impacts and regulatory policy implications spray disposal of dredged material in Louisiana wetlands. Coast. Manag. 1988, 16, 341-362. [CrossRef]

128. Lester, G.D.; Sorensen, S.G.; Faulkner, P.L.; Reid, C.S.; Maxit, I.E. Louisiana Comprehensive Wildife Conservation Strategy; Louisiana Department of Wildlife and Fisheries: Baton Rouge, LA, USA, 2005; p. 455.

129. Teal, J.M.; Weinstein, M.P. Ecological engineering, design, and construction considerations for marsh restorations in Delaware Bay, USA. Ecol. Eng. 2002, 18, 607-618. [CrossRef]

130. Peterson, S.B.; Teal, J.M.; Mitsch, W.J. Delaware Bay Salt Marsh Restoration. Spec. Issue Ecol. Eng. 2005, 25, 199-314.

131. Slocum, M.G.; Mendelssohn, I.A.; Kuhn, N.L. Effects of sediment slurry enrichment on salt marsh rehabilitation-Plant and soil responses over seven years. Estuaries 2005, 28, 519-528. [CrossRef]

132. Croft, A.L.; Leonard, L.A.; Alphin, T.; Cahoon, L.B.; Posey, M. The effects of thin layer sand renourishment on tidal marsh processes: Masonboro Island, North Carolina. Estuaries Coasts 2006, 29, 737-750. [CrossRef]

133. Shaffer, G.; Day, J.; Lane, R. Optimum use of freshwater to restore bald cypress-water tupelo swamps and freshwater marshes and protect against salt water intrusion: A case study of the Lake Pontchartrain Basin. In Mississippi Delta Restoration; Day, J., Erdman, J., Eds.; Springer: New York, NY, USA, 2018; pp. 61-76.

134. Hunter, R.; Day, J.W.; Lane, R.; Shaffer, G.; Day, J.N.; Conner, W.; Rybczyk, J.; Mistich, J.; Ko, J. Using natural wetlands for municipal effluent assimilation: A half-century of experience for the Mississippi delta and surrounding environs. In Multifunctional Wetlands, Environmental Contamination Remediation and Management; Nagabhatla, N., Metcalfe, C., Eds.; Springer: New York, NY, USA, 2018; pp. 15-81.

135. McLindon, C. Using Oil and Gas Industry Data to Achieve Coastal Sustainability. SOC Block VI. Available online: https://sites.law.lsu.edu/coast/2016/06/state-of-the-coast-2016/ (accessed on 3 March 2020).

136. Wiegman, R.; Day, J.; D’Elia, C.; Rutherford, J.; Morris, J.; Roy, E.; Lane, R.; Dismukes, D.; Snyder, B. Modeling impacts of sea-level rise, oil price, and management strategy on the costs of sustaining Mississippi delta marshes with hydraulic dredging. Sci. Total Environ. 2017, 618, 1547-1559. [CrossRef]

(C) 2020 by the authors. Licensee MDPI, Basel, Switzerland. This article is an open access article distributed under the terms and conditions of the Creative Commons Attribution (CC BY) license (http://creativecommons.org/licenses/by/4.0/). 